\title{
Mies and his Teaching Venues. The Triumph of Architecture over Function
}

\author{
Laura Lizondo-Sevilla ${ }^{1}$ | José Santatecla-Fayos ${ }^{2}$ | Zaida Garcia-Requejo ${ }^{3}$ \\ Recibido: 26-06-2020 | en su versión final: 05-11-2020
}

Abstract

\begin{abstract}
Mies van der Rohe started teaching architecture in 1930, the year he was appointed head of the Dessau Bauhaus. Political upheavals in Germany at that time obliged him to move to new premises and even to a new country: in 1938 he emigrated to the USA as head of the architecture department at the Armour Institute of Technology. In the twenty-eight years from his early days at the Bauhaus to his retirement from the school in Chicago, teaching was one of his main activities: classrooms were an ideal laboratory for experimenting with and thinking about architecture, and as a working architect he invariably brought his experience into the classroom. The aim of this paper is to examine the links between Mies' teaching, thinking and architecture more closely in order to determine the connection between his teaching of architectural design and his work as an architect. However, within such a wide field, this paper focuses on a specific typology: the school of architecture. The hypothesis to be answered is: did Mies' experience as a professor, and the professional and academic homologous projects in which he was involved, play a decisive role in the design of the only venue he built from scratch for teaching architecture: the open-plan Crown Hall? The research methodology employed consisted of revising, analysing and redrawing the different venues where Mies taught architectural design and comparing them with research projects about this typology. The ideas presented in dissertations directed by Mies about designing schools of architecture were of particular interest for this paper.
\end{abstract}

Keywords: Mies van der Rohe; Bauhaus; Illinois Institute of Technology

Citation

Lizondo-Sevilla, L. et al. (2021). Mies and his Teaching Venues. The Triumph of Architecture over Function, ACE: Architecture, City and Environment, 15(45), 9517. DOl: http://dx.doi.org/10.5821/ace.15.45.9517

\section{Los espacios docentes de Mies. La Arquitectura supera la función}

Resumen $\quad$ Mies van der Rohe se inició en la docencia del proyecto arquitectónico en 1930, año en el que fue nombrado director de la Bauhaus de Dessau. Tras sustanciales cambios políticos acontecidos en Alemania, que le obligaron a cambiar de sede e incluso de país, en 1938 emigró a los Estados Unidos como Director del Departamento de Arquitectura del Armour Institute of Technology. Durante los veintiocho años que transcurrieron desde la Bauhaus hasta su jubilación en la escuela de Chicago, la enseñanza fue una de sus dedicaciones principales: las aulas fueron el taller proyectual ideal para ensayar y reflexionar su profesión y su oficio de arquitecto le exigió trasladar dicha experiencia a los espacios docentes. El presente artículo tiene como objetivo general ahondar en el vínculo entre docencia, pensamiento y arquitectura en Mies, a fin de relacionar su enseñanza de proyectos y su práctica profesional. Sin embargo, dentro de un campo tan amplio, el artículo estudia específicamente la tipología de escuela de arquitectura. La hipótesis por responder es: ¿ fue su experiencia como profesor y los proyectos homólogos en los que se involucró, profesional y académicamente, determinantes en la concepción de su único espacio construido ex-novo para la enseñanza de la arquitectura, el espacio unitario del Crown Hall? La metodología utilizada consiste en revisar, analizar y redibujar los distintos espacios en los que practicó la enseñanza del proyecto arquitectónico y compararlos con los proyectos investigados en torno a esta tipología. Las ideas presentadas en las tesinas dirigidas por Mies sobre el diseño de escuelas de arquitectura fueron de particular interés para este trabajo.

Palabras clave: Mies van der Rohe; Bauhaus; Illinois Institute of Technology

1 B.Arch. PhD, Universitat Politècnica de València (ORCID: 0000-0003-0376-0593, WoS ResearcherID: G-2167-2016, Scopus Author ID: 55792158200), ${ }^{2}$ B.Arch. PhD, Universitat Politècnica de València (ORCID: 0000-0002-0356-6646, WoS ResearcherID: AAW-1511-2020, Scopus Author ID: $\underline{5792178100)}$ ) ${ }^{3}$ B.Arch. PhD, Universidade da Coruña (ORCID: 0000-0003-4743-815X, WoS ResearcherID: ABE-7783-2020, Scopus Author ID: 57212168309). Contact e-mail: laulise@pra.upv.es 


\section{1. "A Curriculum of Ideas": A New Practice in Architectural Design Education}

Mies van der Rohe did not train as an architect in academic realms but according to a curriculum of his own design which provided an understanding of the basics of architecture ranging from materials to the project. He never studied at any university or school of architecture and was never taught a curriculum guaranteed to equip him with the knowledge needed to work as an architect. He simply learnt the architect's trade gradually: first in his family's workshop and then in the different studios where he worked. As a result of the skills, he learnt at the Spenrathschule ${ }^{1}$ and the years he spent developing his drawing ability -at the plaster design workshop run by Max Fischer in Aachen, at Schneider's architecture studio also in Aachen, at the town hall in the Rixdorf district of Berlin, and finally in the studios of the architects Bruno Paul and Peter Behrens -Mies believed that architects should basically start by learning to draw clearly and accurately. Likewise, the craftmanship that Mies learnt from his father and his work as an apprentice as a young man in nearby projects were reflected in the meticulous attention that Mies always paid to understanding materials and their properties, and to order when using them in construction: order in the sense used by St Augustine, i.e., the rightful place of materials according to their essence.

This path towards becoming a self-made man undoubtedly influenced his method and approach to the teaching of architecture and provided the guiding principle for the curriculum that Mies announced during his inaugural address as head of architecture at the Armour Institute of Technology (AIT, 1938), Chicago, and was implemented in the Program for Architecture Education. Mies believed that the best way to learn about architecture depended not on course content but practice. "Try it again" (Honey, 1986, p. 45) Mies would tell his students, encouraging them to try out different concepts, types of buildings, details, joints... repeatedly. His approach to teaching never contemplated lectures, far from it, he regarded training in architecture as the stuff of workshops where expert masters with years of experience could share the secrets of the trade with apprentices. "It is in the studio that the actual process of learning in order to become an architect takes place" (Malcolmson, 1986, p. 6). Indeed, to quote Franz Schulze, the teaching venue was inspired by the Bauhüte "that medieval shelter where designer, contractor, craftsmen, and labourers worked in close proximity" (Drexler \& Schulze 1985, p. 206).

As head of the Bauhaus, he not only gave classes but had other academic responsibilities such as reviewing and improving the curriculum designed by previous directors. This practical and theoretical experience stood Mies in good stead for designing and planning from scratch the curriculum that he subsequently implemented, as mentioned above, whilst head of architecture at the AIT. Although Mies took the practices of other schools of architecture into account, the mainstay of his approach was his own experience combined with an innovative teaching method: he encouraged his students to think2. "He rarely corrected a student's work or showed them how a design should be better. Rather, he told them in front of their drawings that something would not work, that a better solution to this or that was needed" (Banham, 1986, p. 14), or as Mies himself said, "We don't teach them solutions; we teach them a way to solve problems" (Cohen, 2018, p. 100). To do so and enable them to assimilate their own discoveries, he encouraged what is now known as transversal teaching between students in different years: "everybody's business was everybody else's business - or could be. The accumulative wisdom and experience of each year above was handily available to each year below, to be tapped by observation, discussion or intellectual osmosis" (Banham, 1986, p. 14). Hence, based on individual thinking and group learning, the curriculum was then drawn up starting with the simplest

\footnotetext{
1 "The trade school", Mies recollected, "was not the same as a crafts school. It offered the kind of two-year course that would enable a graduate to get a job in an office or a workshop. Great stress was laid on drawing because it was something everybody had to know. You understand, the curriculum was no theoretically contrived program. It was based on experience, on the sort of thing tradesmen really had to use" (Schulze \& Windhorst, 2012, p. 10).

2 "The curriculum includes all of the subjects taught in architectural schools elsewhere. The superiority of this school over the others lies in the aim of the teaching and in the way the courses are taught" (Dearstyne, 1944, p. 5).
} 
aspects and progressing to the most complex: first, drawing ability and visual perception; second, the study of materials and construction; and finally, the study of function as a way of understanding space (for more on this topic see Malcolmson, 1959; Mies van der Rohe, 1951).

However, although it is useful to research innovative methods of teaching architecture, it is also important to study the architectonic conditions of the places where such teaching takes place. The first specific aim of the present article is to examine the venues (some barely documented) where Mies gave classes in architecture by describing them and situating them in his career as an architect and professor. This leads to the second specific aim, i.e., to study which school of architecture projects were designed or built by Mies - the aim being to pinpoint possible variables that could provide important insights into Mies' open plan design for S.R. Crown Hall, the home of the School of Architecture at the Illinois Institute of Technology (IIT) ${ }^{3}$, Chicago: his ideal place for teaching, even though he only taught there for the last two years of his teaching career.

Although Mies' teaching career is often associated with the IIT - including the impressive open-plan Crown Hall - and, albeit to a far lesser extent, the Bauhaus, it must be remembered that Mies taught architecture for almost thirty years from the Dessau Bauhaus to the Chicago Crown Hall. Teaching was so important to him that he used his own funds to transform an old factory in Berlin into a school, with help from fellow Bauhausers, when they were forced out of the previous premises in Dessau. Even during the three months between the Bauhaus being shut down by the Gestapo and its definitive closure - a decision Mies took after rejecting the impositions of the German government Mies continued to teach. He would correct projects in his studio and organise field trips to visit architectures and keep the Bauhaus family united. As mentioned in letters by Bauhaus students, Mies recommended them to visit specific buildings in Berlin and organised outings together with Lilly Reich to places such as Postdam and Charlottenhof, sometimes by boat along the city canals. In the words of Fritz Neumeyer (2019), "Bauhaus exists outside Bauhaus", it extends beyond the confines of the classroom. Mies' concept of architecture was something to be experienced with emphasis on aspects such as integration into the landscape, the simplicity of structure and the relationship between the interior and exterior. He continued to organise outings after the definitive closure of the Bauhaus as revealed by his trip to Lugano with Reich and five students, and extant drawings confirm the trips, discussions and corrections that took place in the late summer of 1933. Despite the increasingly hostile attitude towards modern architecture in his homeland, Mies resisted the temptation to emigrate to the US and only succumbed when some of his former students already living there suggested Chicago would be the perfect place for an architect and lecturer. Mies obviously regarded the teaching of architecture as an integral part of an architect's career, two sides of the same coin: practicing architects needed to share their experience in the classroom, and the classroom was a laboratory for trying out new methods to be used in professional architecture.

There is no doubt that a man like Mies, an untiring critical thinker, gave a great deal of thought to the optimum conditions for a place where this admirable activity could be carried out. It is therefore reasonable to assume that the experience in architecture that Mies acquired at the Gropius Bauhaus and other places where he taught did influence the design of Crown Hall: his own classroom archetype. Since Crown Hall was the only school of architecture that Mies designed and built from scratch in his studio, the authors decided to locate and study the projects he taught in classrooms about this typology, so this paper examines on the one hand Mies experience as a teacher and on the other, the dissertations about schools of architecture that he directed, to see whether they influenced the design of Crown Hall. It must, however, also be remembered that Mies' ideas about the ideal place for teaching architecture embraced more than functional considerations. For this reason, the openplan design of Crown Hall was an opportunity to try out his architectural tenets, such as his research into the abstract concept of universal space: the proof of purpose and spirit, the methodical simplification of construction, the logic of structure. In other words, a form of architecture that

${ }^{3}$ In 1940, the Armour Institute of Technology merged with the Lewis Institute to form the Illinois Institute of Technology.

ACE, 15 (4.5) CC BY-ND 3.0 ES | UPC Barcelona, España | Mies and his Teaching Venues. The Triumph of 
eliminates all non-essentials and transcends functional requirements, i.e., spatial compartmentalisation, and provides instead a fluid, open-plan space able to cater for different functions and thereby ensure it survives the passage of time (Santatecla et al., 2010, p. 58).

\section{2. "Inside the Bauhaus": Dessau and Berlin, 1930-1933. The Triumph of Function}

Mies van der Rohe's teaching career began in August 1930 when he became head of the Bauhaus. His rather unorthodox, hands-on training influenced how he taught architecture. His experience in his father's stonemasonry business, the skills acquired at the Spenrathschule, his work as a draftsman, and the design courses he was taught by Bruno Paul, all made him a staunch supporter of drawing and construction as the basis of architectural design. Likewise, his experience in Peter Behrens' studio, where he oversaw projects for the A.E.G. turbine factory, initiated him into a new sphere of architecture, "a distinct industrial classicism where opposing worlds of industrial technology and ceremonial art were reconciled" (Neumeyer, 1986, p. 29). All this experience, combined with Mies' love of philosophical writings and his first-hand study of different forms of architecture such as those by Karl Friedrich Schinkel first and subsequently those by Hendrik Petrus Berlage, equipped Mies with the full range of modern concepts which formed the basis of his own method of teaching architecture, i.e. drawing, construction and technology together with the philosophical and spiritual values that characterised the culture and civilisation of that period. By applying these philosophical and practical premises, Mies created a more well-balanced version of the curriculum implemented in 1919 at the Bauhaus school by Walter Gropius and subsequently modified by Hannes Meyer. Gone were the Gropius teaching methods that regarded artists and craftsmen as equals. Gone was the excessively scientific approach that Meyer applied to social and political activities. Mies proposed a combination of art and technology featuring an architectural project, a way of studying architecture, vocational training and technical skills that placed greater importance on the architect's education. As a result, "the Bauhaus became a school of architecture" (Honey, 1986, p. 45). The Bauhaus in Dessau was a purpose-built complex designed by Walter Gropius to house an art trade school and the Bauhaus art school, two functions in different buildings linked by a bridge in housed the administrative offices of the two entities. When Gropius began work on the Dessau Bauhaus in 1923, the aims of the entity and the functional organisation of the building had already been tried and tested: a small community, an exceptionally low student-teacher ratio, and teaching based on practical workshop sessions (Añón, 2010, p. 35). The aim of Gropius' project was to demonstrate the functionalist idea and strike a balance between technological innovation, industrialised production and the craftsman's control of the work of art. To quote a student who used these facilities during the seven-year life span of the Dessau Bauhaus, "this modern style, I believe, is bound to have a great future. It is as simple as possible, without decoration, frills or unnecessary elements. It is the architecture of the modern mechanical age" (Dearstyne, 1962, p. 14).

The Bauhaus Architecture Department occupied a large, L-shaped space on the upper storey of the bridge. Mies gave his classes in the lecture room, the largest area in the department and the only one with natural daylight on both sides, due to its corner location (Dearstyne, 1986, p. 222). The school had quite a classical functional layout with large, well-lit, neutral spaces. The building's concrete structure was part of the interior design of the classrooms whose only furnishings were cork panels on windowless walls and lines of parallel desks at right angles to the glass façades (see Figures 1 \& 2). Within this effective, functional space, Mies' teaching style was transversal, personal and approachable, although many of his students subsequently described him as "arrogant and nervewracking" (Hochman, 1989, p. 83). "The teaching method was quite informal. (...) I enter the room in which the lectures are given and sit down a little away from the others. They come in one by one and find places on table, benches, stools and window benches. They debate (...) Opinion class" (Honey, 1978 , p. 55). The design studio classroom was where the drawings and mock-ups of students' projects 
were to be found. In the specific case of the Bauhaus, it was the projects for the famous Court Houses that took over the learning area, this being the typology that virtually monopolised Mies classes in Germany (for more on this topic see Fornari, 2015; Riley, 2001).

Figure 1. Second floor plan, Bauhaus Dessau, Walter Gropius, 1925

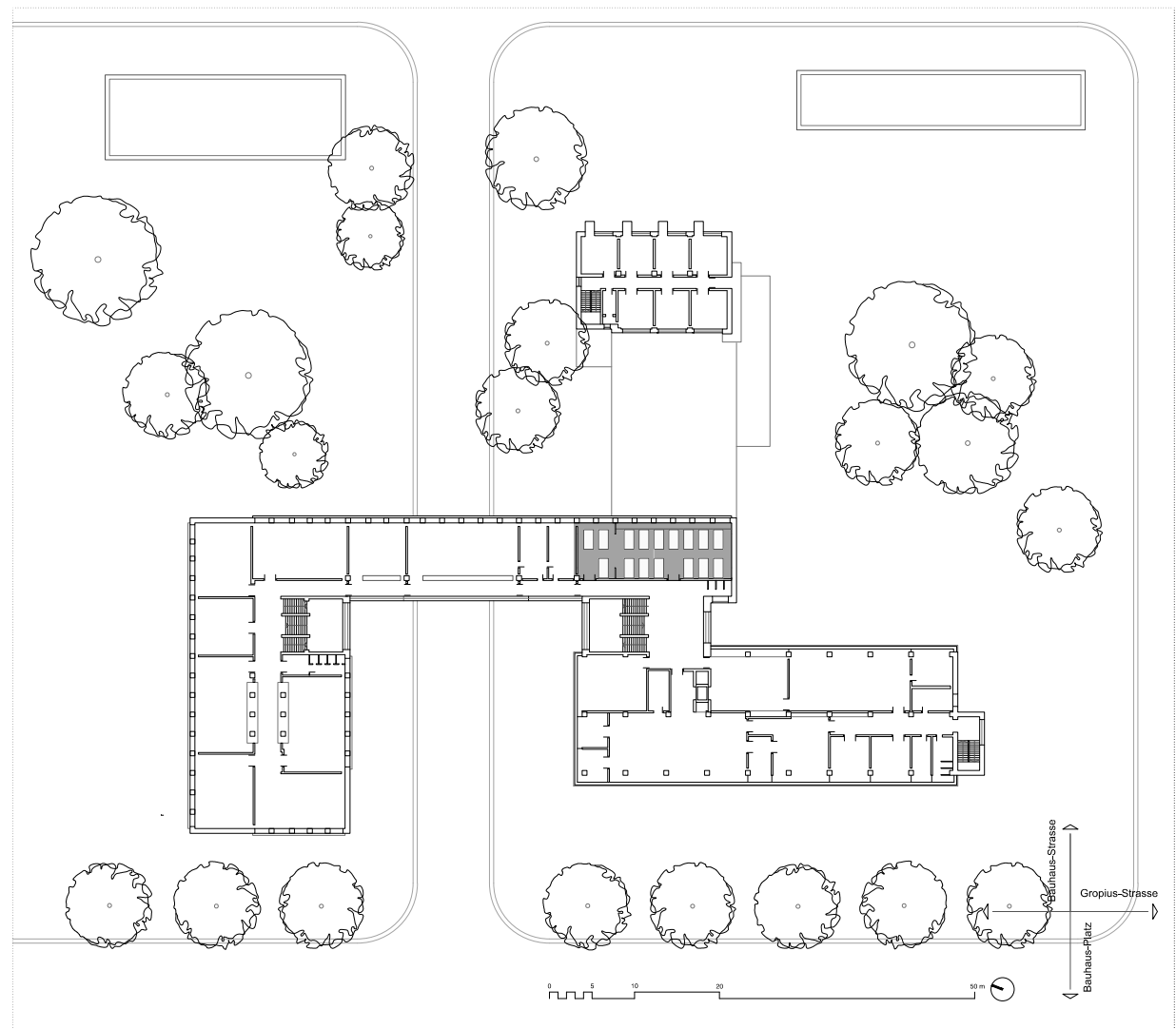

In grey: lecture room with furniture (Mies' class).

Source: Authors' drawing.

Figure 2. Mies van der Rohe conducting a seminar at the Bauhaus with students Annemarie Wilke, Heinrich Neuy and Herman Klumpp, Dessau, Germany, 1931

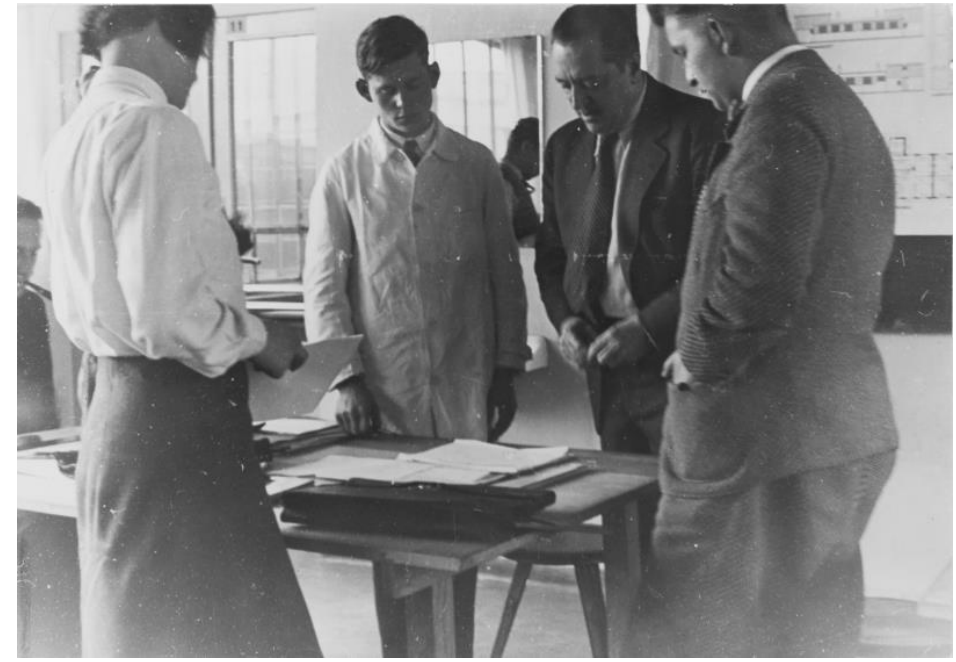

Source: Pius E. Pahl, photographer. @ Canadian Centre for Architecture.

ACE, 15 (4.5) CC BY-ND 3.0 ES | UPC Barcelona, España | Mies and his Teaching Venues. The Triumph of 
As Neumeyer (2019) explained, during this period, Mies regarded housing as the architectonic typology par excellence and considered research into the relationship between the interior and exterior of a house to be sufficient instruction for a student of architecture. As a result, none of the projects directed by Mies in this period concerned the school of architecture typology. Terence Riley (2001) mentions this two-way teaching process about the Court Houses: this eminently inward-looking type of housing enabled students of architecture to learn about and Mies to develop the connection between interior and exterior space. It is, therefore, no coincidence that Mies was giving classes about court houses at the Bauhaus at the same time as he was working on this type of housing in his studio. Figure 3 shows the works directed by Mies during his teaching career and shows that all the projects by his students during his time in Germany focused on housing.

Mies never mentioned the Gropius building or the spatial considerations of its classrooms or the workshops where buildings were erected on a 1:1 scale, at least not in his writings. He only referred to it in conceptual terms: the "great and pretentious idea" of Gropius (conference published in Giedion, 1954, pp. 20-22). It is, however, undeniable that the Gropius building, characterised mainly by its functionality and contemporary nature, fulfilled the principles that Mies championed in his writings of that period about the meaning of architecture: a building suitable for its intended purpose and in keeping with the spirit of a new, decidedly industrial era. So much so, that when the Dessau Bauhaus was forced to close in August 19324, Mies replicated the same functional model - within the physical constraints of the existing factory premises - for the new Bauhaus in Berlin that opened immediately after, on 1 October 1932.

Mies himself dealt with the paperwork of the Bauhaus move in record time, and likewise the search for and rental of its new premises: an old telephone factory on Birkbuschstrasse in the Steglitz district of Berlin (see Figures $4,5 \& 6)^{5}$. This building, since demolished, was two storeys high and had a symmetrical façade featuring bare brick and large windows. Each storey was open plan in keeping with its previous use. This made it quite easy to create the areas needed for classes at the Bauhaus, and reduced costs considerably - another important factor because Mies had few resources to cover the cost of adapting the interior areas of the factory to their new teaching purpose. Led by Mies, students joined forces to scrape, clean, plaster and paint the interior walls of the old building. They also erected partition walls to create classrooms and offices with a layout like that of the building in Dessau (see Figure 7). By studying the floor plan space and comparing it with the few extant images, it has been possible to determine where teaching took place: once again in the largest space with the best illumination, thanks to its three façades, and with the structure of the building visible in its interior.

However, the comparison of this renovation with the works Mies carried out in his studio, such as his ephemeral architectures (Lizondo et al., 2014), his recently completed Villa Tugendhat, or his unbuilt courtyard houses, reveals a surprising spatial distribution: a fractioned layout that he even used in the factory next door bought in January 1933. Those premises consisting of a single floor with skylights were intended to house the printshop belonging to the press department run by Josef Albers -a space that was deemed essential for the teaching and artistic aims of the Bauhaus, particularly in Berlin where the Nazi regime was very unsympathetic to its interests-. The floor plans are compartmentalised in a similar way to the Gropius Bauhaus, considering the physical constraints of the existing premises, the numbers of students and the requirements of the work areas. This approach was not so much in response to the actual circumstances as to what Mies had in mind when he designed this school, because actual attendance was considerably lower than the numbers who enrolled according to the list dated March 1933 (Hahn, 1985, pp. 103-105).

\footnotetext{
4 “On August 22, 1932...The 'sombre glass palace of oriental taste', the so-called 'aquarium' -the Dessau Bauhaus, that incubus of 'Jewish-Marxist' art- was finished” (Hochman, 1989, p. 101).

5 “To enable it to rent a 'terribly black' old, deserted telephone factory in Steglitz, Mies put up 27,000 marks, a considerable sum of money of his own" (Hochman, 1989, p. 102).
} 
Figure 3. Comparison of the projects designed by Mies in his studio and in his classrooms

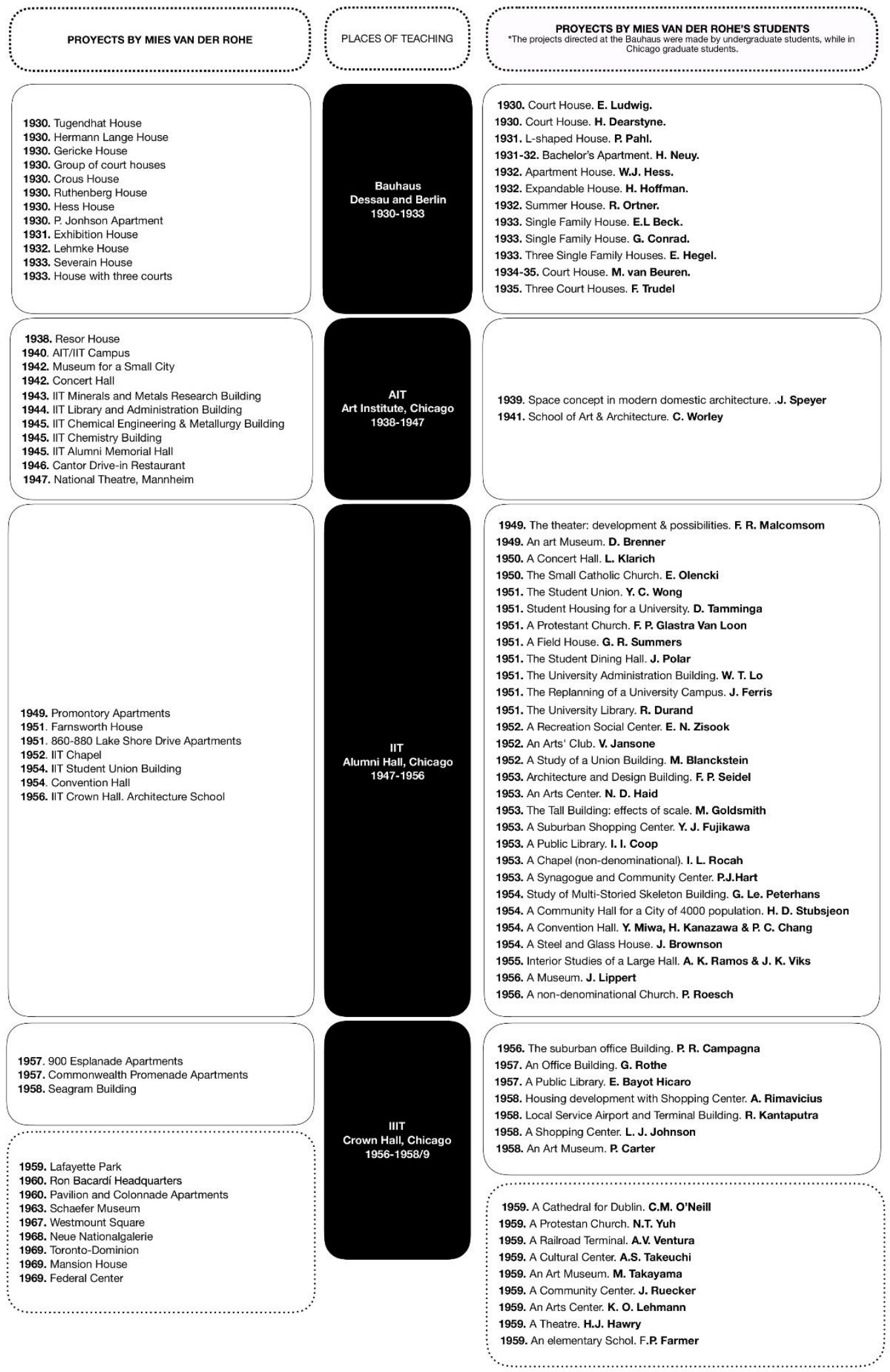

Source: Own elaboration based on the archive research.

ACE, 15 (4.5) CC BY-ND 3.0 ES | UPC Barcelona, España | Mies and his Teaching Venues. The Triumph of 


\section{ACE Architecture, City and Environment}

E-ISSN 1886-4805

Figure 4. First and second floor plans, Bauhaus Berlin, Mies van der Rohe (remodelling of the telephone factory on Birkbuschstrasse, Steglitz district), 1932

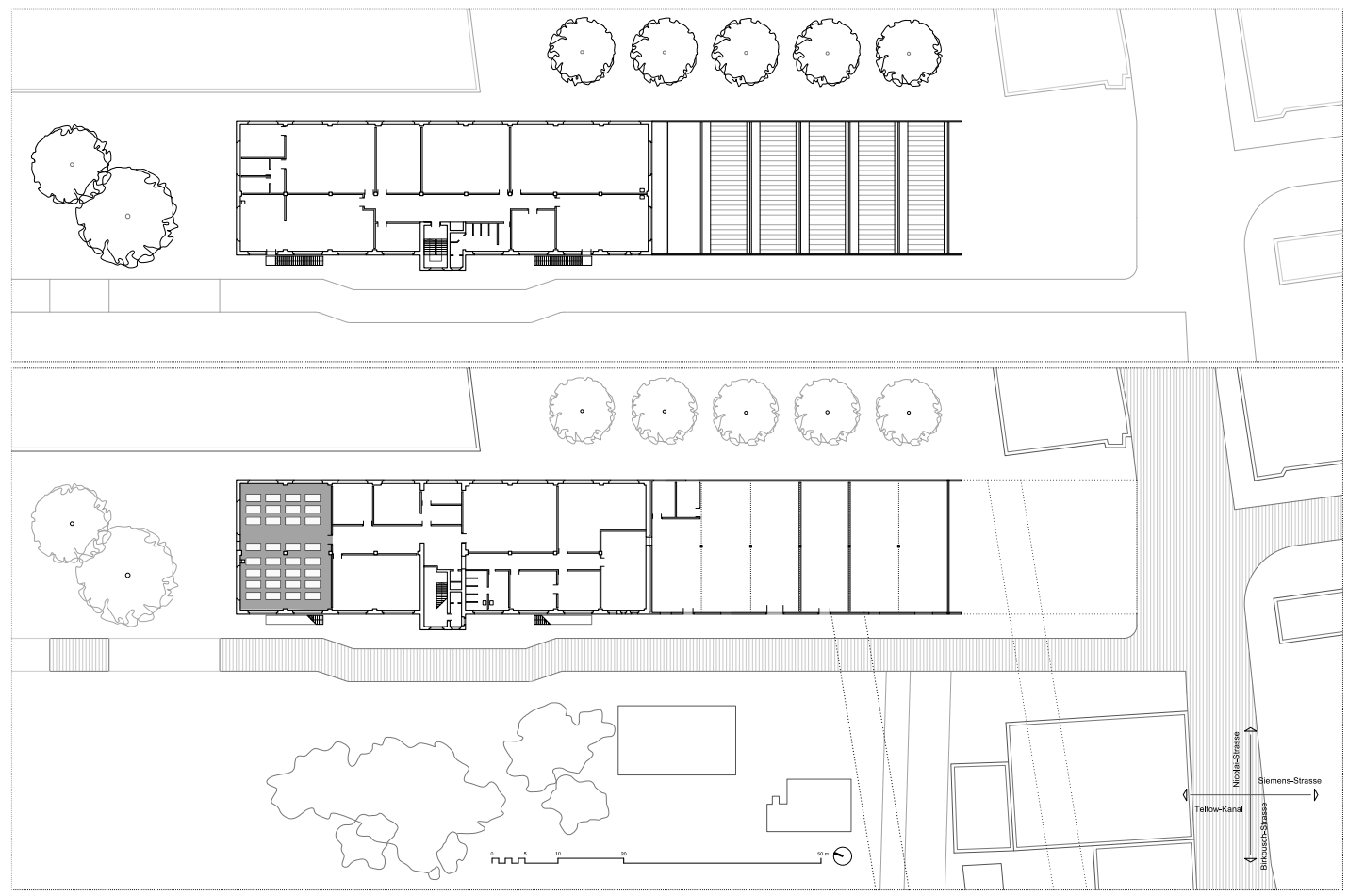

Note: In grey: lecture room with furniture (Mies' class).

Source: Authors' drawing

Figure 5. Mies teaching at the Berlin Bauhaus, 1933

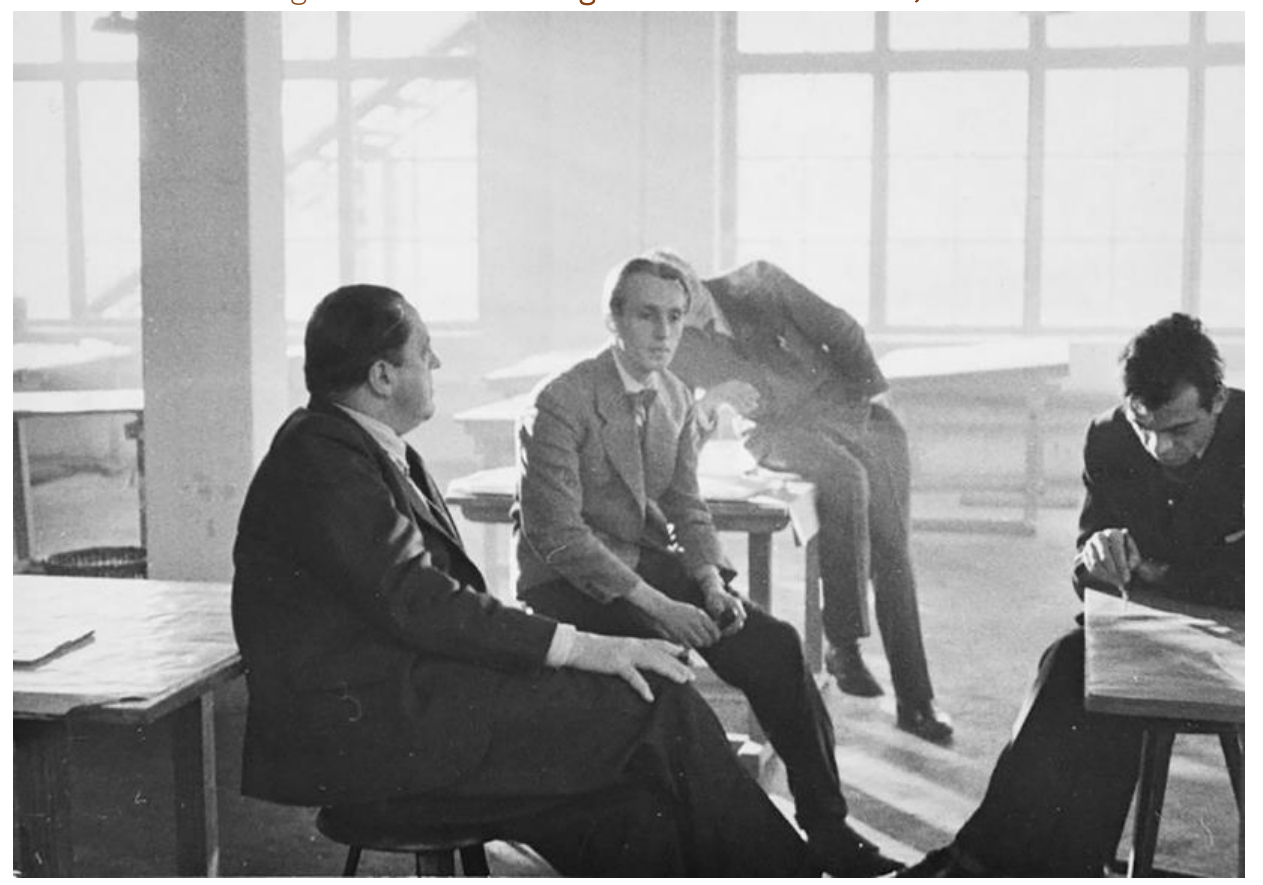

Source: Harvard Art Museums/Busch-Reisinger Museum, Gift of Howard Dearstyne. @ President and Fellows of Harvard College.

ACE, 15 (4.5) CC BY-ND 3.0 ES | UPC Barcelona, España | Mies and his Teaching Venues. The Triumph of 


\section{ACE Architecture, City and Environment}

E-ISSN 1886-480

Figure 6. Berlin Bauhaus, 1932

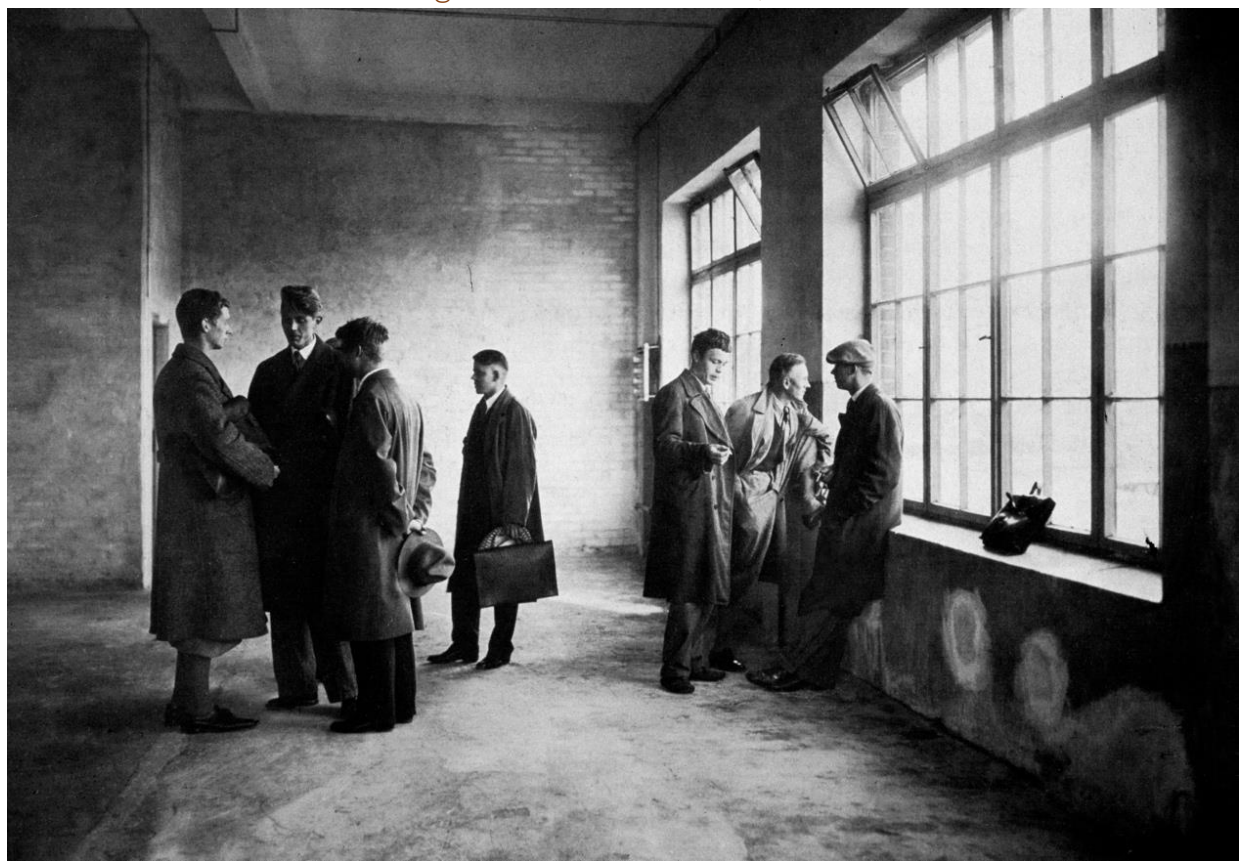

Source: (c) Album / akg-images

Figure 7. Students visiting the factory that was to house the Berlin Bauhaus and working on renovation, 1932

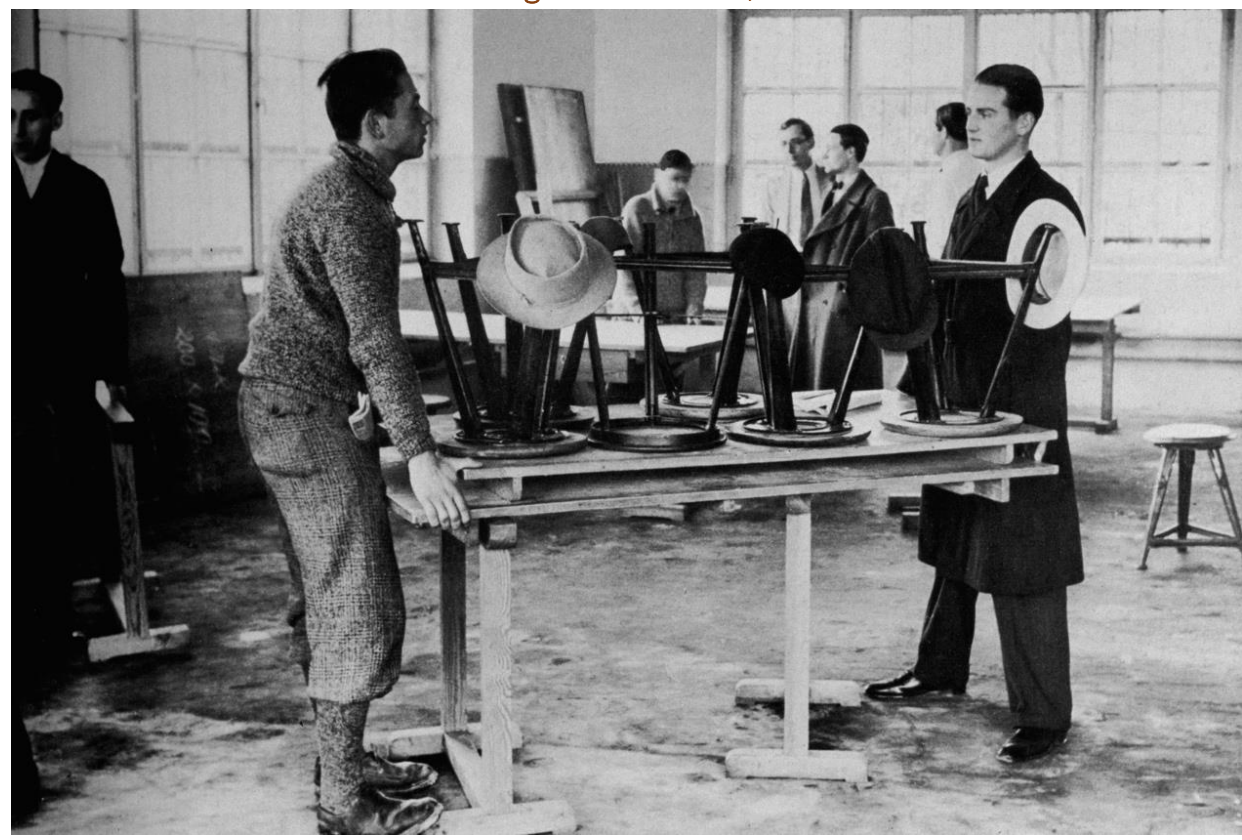

Source: () Album / akg-images.

In addition, Mies' writings in that period also reveal the importance he gave to certain concepts that he deemed typical of the new spirit of the era, such as the negation of form and the championing of functional aspects of architecture. Mies' earliest texts assert the negation of formalism, in the sense of a formal idea conceived of a priori, a concept that must be viewed in the context of the discussions of the German avant-garde during the inter-war period from 1919 to 1939, the struggle between

ACE, 15 (4.5) CC BY-ND 3.0 ES | UPC Barcelona, España | Mies and his Teaching Venues. The Triumph of 
expressionism and rationalism, or between intuition and logical reasoning, and the search for the great objective style advocated by Nietzsche who regarded everything stemming from the world of science, technology and industry as objective values. A style of architecture that had wearied of late nineteenth-century neo styles and turned its eye to the formal achievements of engineering, with no preconceived formal concepts, and the desire to fulfill the needs of humanity. A style of architecture whose beauty lay precisely in being or fulfilling its intended purpose. Form follows function (Mies van der Rohe, 1923, p. 243).

His early writings also mention the functionalist approach, rather than the fulfilment of purpose, as the only possible means for the new architecture. The functional program is what underpins the discovery of new architectonic forms that no longer stem from the artist's free will but from the artist's submission to strictly objective values. Nevertheless, Mies took another step forward and qualified the concept of utility by associating the words useful and meaningful (Mies, 1930, p. 2). He discarded impracticalities as meaningless and plunged into the controversy of utility versus beauty whilst denying any contradiction. Mies regarded them not as opposites but as complementary values: useless, meaningless beauty cannot be understood. Architecture, however, cannot content itself with producing useful forms. Mies saw beauty as an end, an essential part of every work of architecture as it always has been. He then quoted St Augustine's medieval proverb for the first time, "Beauty is the radiance of truth!" (Mies, 1930: 2) thereby combining both values in a single ontological reality.

Thus, the main intention of Mies' writings prior to 1933 was to champion the negation of form and assimilate the importance of function as a cornerstone of the design process. Mies regarded function as the perfect fit between architecture and the requirements of humanity in the new era and understood function to do more than merely satisfy the specific needs of each case. Starting in 1933, Mies took a break from his critical writings and did not publish anything until he settled in the US and was appointed director of the AIT architecture department in 1938. In the interim period, he dealt with the closure of the Berlin Bauhaus in July 1933 and, after several years' thinking, took the decision to pursue his career in architecture and teaching in Chicago, where he began a conceptual evolution that would lead to the triumph of space over function.

\section{3. "Architectural Education at IIT": Chicago, 1938-56. Space Transcends Function}

From 1895 to 1945, the Department of Architecture at the AIT was housed in the Art Institute, a building erected for the Chicago Columbian Exposition of 1893. It was used for classes and as a museum and was regarded as one of the main cultural centres in the US. Mies' teaching career in the US began as head of the AIT Architecture Department in the autumn of 1938, in none other than this iconic building.

As in the case of the Bauhaus premises in Berlin, truly little written and graphic documentation has survived about the spatial and architectonic conditions of the school located on the third floor of the Art Institute: just a handful of images and descriptions by a few students. The study of the few extant images and drawings of the building reveals frugal classrooms. Their walls were made of concrete blocks covered merely in a coat of white paint that partly compensated the lack of daylight coming in from the outside. One of the interesting extant documents about the subject under study here is a descriptive manuscript by the student Thomas Burleigh (1998). Amongst other things, Burleigh said that although the architecture department, located in the attic space over the front galleries of the Art Institute, was not the best place for teaching, its cultural value transformed any discomfort into encouragement, and the winding path to the attic through the art galleries enabled students to enjoy the exhibitions (see Figures 8 \& 9). The rooms for the freshman sophomores and graduates were lit by windows in the sloping roof whilst the classrooms for the juniors and seniors on the second floor 


\section{ACE Architecture, City and Environment}

of the east wing over the railroad bridge, had no windows at all and only artificial lighting. According to authors such as Jean Louis Cohen, "Mies suggested recruiting a carpenter and a mason and creating a laboratory for full-scale experimentation" (Cohen, 2018, p. 100), but the location of these places forming part of the Bauhaus and combining the idea of architecture as an art and craft, is not known.

Figure 8. Yearbook, Art Institute of Chicago, 1941

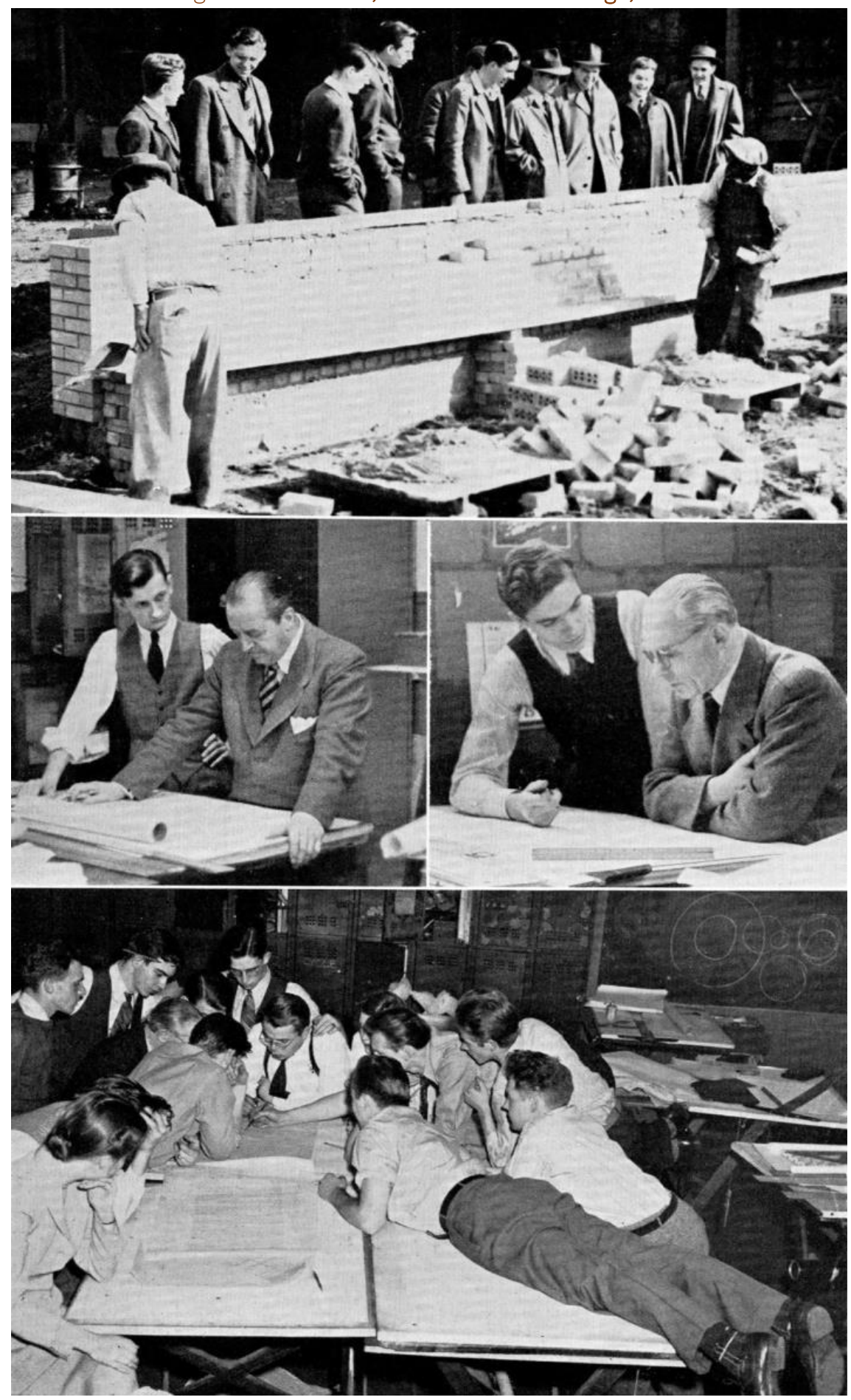

Source: (๑) University Archives and Special Collections, Paul V. Galvin Library, Illinois Institute of Technology.

ACE, 15 (4.5) CC BY-ND 3.0 ES | UPC Barcelona, España | Mies and his Teaching Venues. The Triumph of 
Figure 9. Third floor plan, Art Institute of Chicago, Shepley, Rutan and Coolidge, 1879

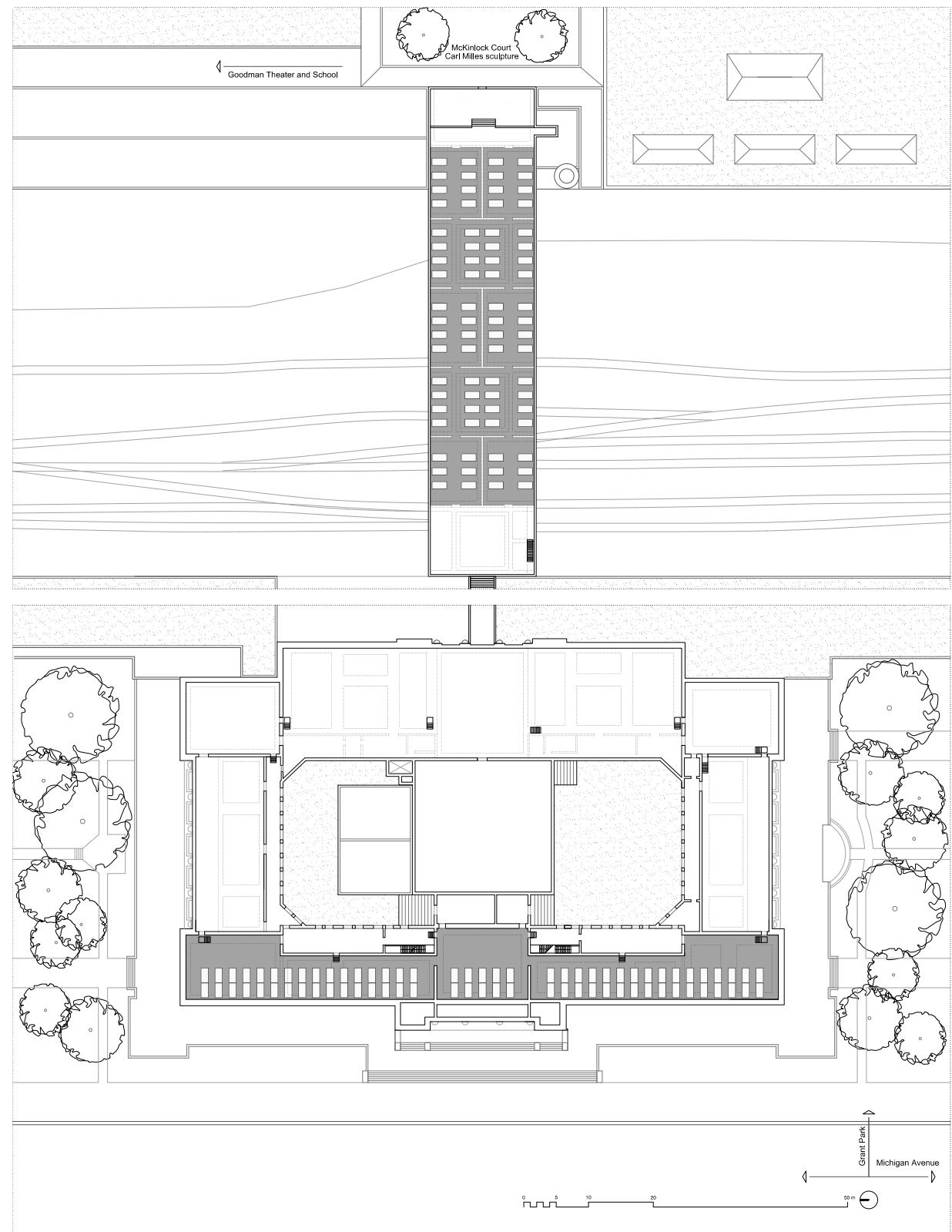

Note: In grey: (top) classrooms for the juniors and seniors, second floor plan; (bottom) classrooms for freshman, sophomores and graduates, third floor plan.

Source: Authors' drawing based on Burleigh's manuscript.

Additionally, the area earmarked for the school of architecture was too small for a growing school and in 1946, some studio classes had to be temporarily held on the eleventh floor of the Gage Building, a fine office building built in 1899 by Holabird \& Roche with a façade designed by Louis Sullivan. "The Gage looked directly across Michigan Avenue, with an unobstructed view down of the roof of the Art Institute and out across Grant Park with the expanse of Lake Michigan beyond" (Burleigh, 1998, p. 8).

Classes were only held in the two buildings for a brief period and in 1947 the Department of Architecture moved to its final location on the IIT campus designed by Mies. Unfortunately, Crown Hall had not even been sketched at that time so once again the Department of Architecture had to 
be installed temporarily (for almost a decade) in a reception building, also designed by Mies, but intended for a different purpose: the recently completed Navy Building whose name was changed to the Alumni Memorial Hall a year later and run by the Naval Reserve Officer Training Corps and the School of Architecture. The Alumni Hall, one of the first buildings designed by Mies on the university campus, complied with the common guidelines he drew up for the other buildings on this campus in order to endow it all with a sense of unity: a structure in keeping with the basic campus module (24 x 24 feet), an indoor distribution in perfect harmony with rhythm of the structure, and a mindful relationship between the glass panels, sections of brick wall, and metal structure.

In the mainly symmetrical distribution, the classrooms were located at each end of the second floor, separated by a double height area known as the Armory. The columns consisting of H-beams clad in concrete were situated inside the building as close as possible to the outer walls at an angle to the façade. On the outside, the structure was hidden by the addition of I-beam mullions that matched the metalwork and were symmetrical at the corner so that brickwork or metalwork could be mounted on either side. Inside the building, the clad structure made its presence felt by outlining the bare brick walls and defining the spatial rhythm (see Figures 10 \& 11).

Figure 10. First and second floor plans, Alumni Memorial Hall, IIT Chicago, Mies van der Rohe, 1945

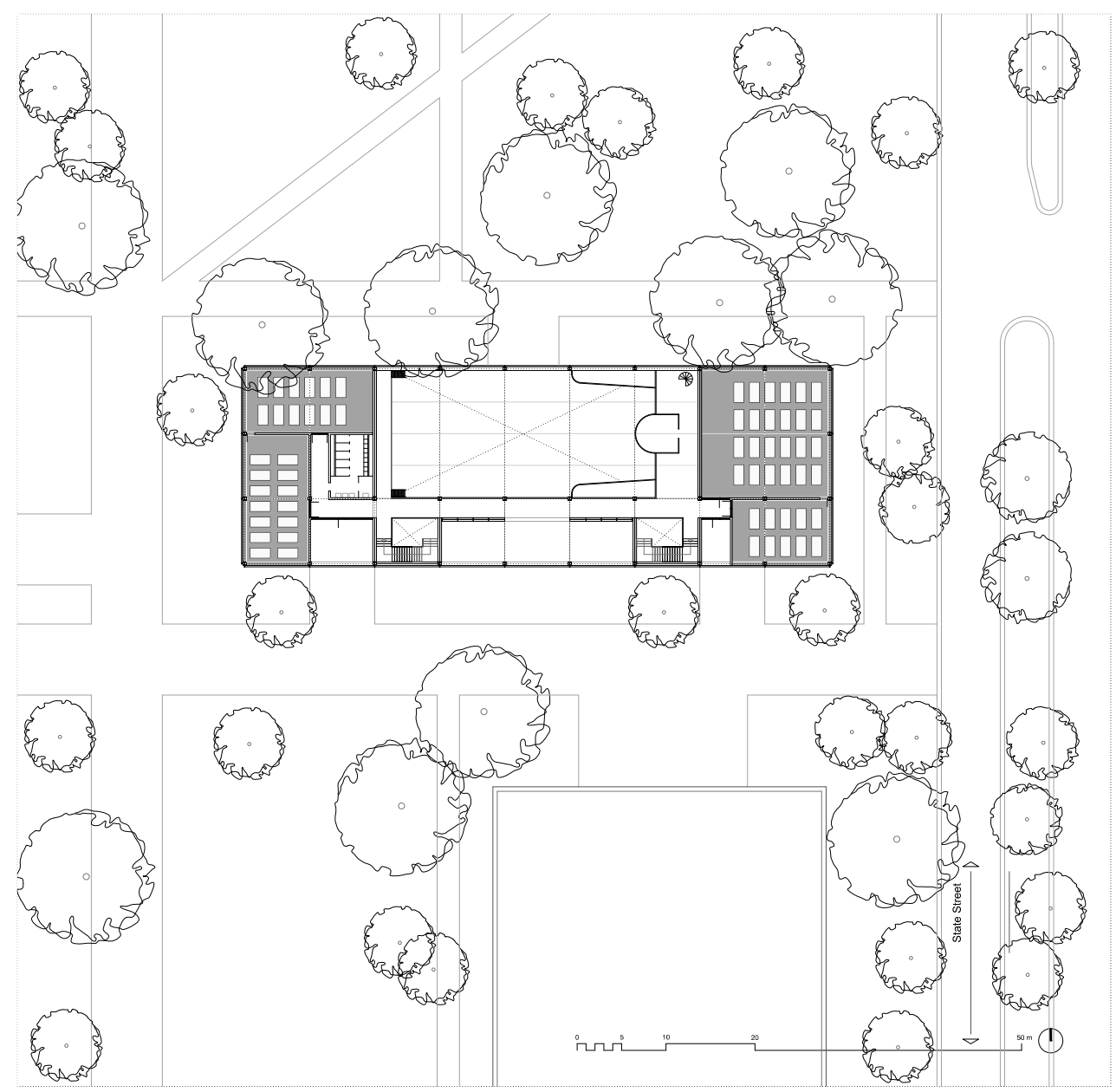

Note: In grey: classrooms with furniture.

Source: Authors' drawing.

ACE, 15 (4.5) CC BY-ND 3.0 ES | UPC Barcelona, España | Mies and his Teaching Venues. The Triumph of 


\section{ACE Architecture, City and Environment}

E-ISSN 1886-4805

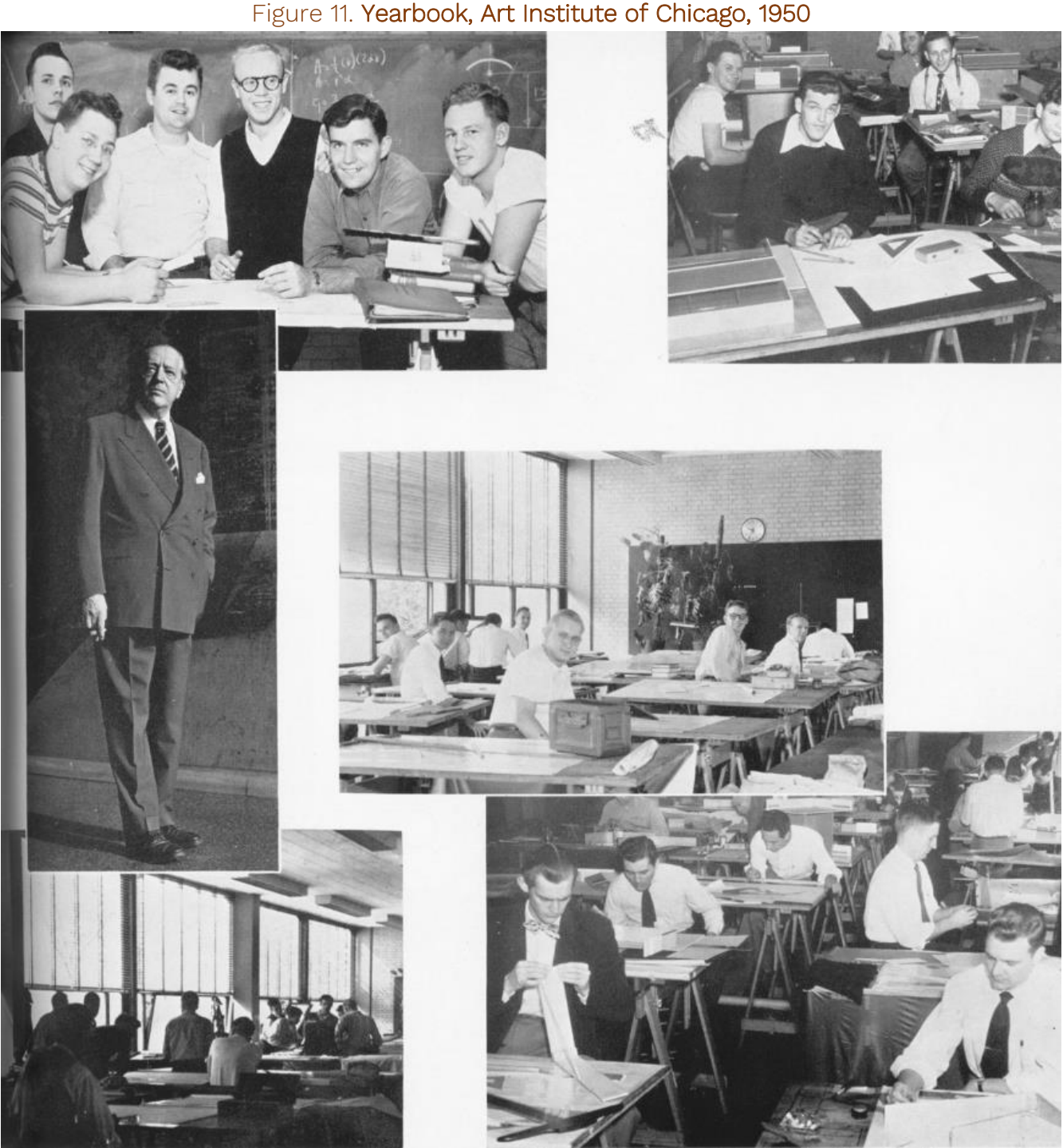

Source: () University Archives and Special Collections, Paul V. Galvin Library, Illinois Institute of Technology.

Although Mies did not design the Alumni Hall as a school of architecture, it is interesting that the building could be used for an activity so different from its intended purpose. This reveals a shift in Mies' work and focus dating from around 1942 when, after settling in the US, he gave function a subordinate role. From then on, his architecture would transcend function, thereby enabling the latter to adapt to changes that could be anticipated over time. Mies subsequently focused on designing a fluid, open-plan layout that could be used for different purposes. This shift in his conceptual approach is also obvious in his writings, although he wrote less than when he lived in Germany. In fact, his most significant writings in the US were just three in number. The first one was the speech Mies gave when he entered the AIT in 1938 in which he championed the idea of moving beyond function and into the realm of spiritual existence, the realm of meanings and the sphere of pure art: "we want to give meaning again to things" (Mies van der Rohe, notebook, 1927-28, p. 62. Published in Neumeyer, 1991, p. 289). He moved beyond the concept of purpose and utility by introducing and qualifying new terms. Mies distinguished clearly between ends and values: ends were related to the objective world outside the individual, whilst values concerned the inner world of the spirit. Once again, however, ends and values were not contradictory concepts but, in keeping with Romano Guardini's theories, 
complementary opposites. For Mies, it was no longer a case of simply fulfilling ends but of finding values that connected with the essence of things. In addition to functional considerations, this text described structure as an essential, key element in the spatial design of the project. Structure, as Mies himself said, is what endows architecture with clarity.

The second important writing was Museum for a Small City, an essay published in 1943 in the journal Architectural Forum, in which Mies asked what museums were for. He examined the concept, pinpointed the essence and devoted the beginning of his article to explaining what a museum should and should not be. He queried the functional program starting with its raison d'être and moved beyond terminology into the spiritual sphere of values. What, in fact, is a museum? It is not simply a matter of organising a functional program but of understanding the crux of the matter and finding an appropriate solution for the main requirements set forth, thereby moving beyond the formulation itself. But apart from this question, said essay was also transcendental for understanding the importance of structure in Mies' architecture. From that project onwards, structure was basically an inherent component of spatial design. Without structure, construction would be impossible. The building consisted of just three components, and all three were structural: "The building conceived as one large area, allows every flexibility in use. The structural type permitting this is the steel frame. This construction permits the erection of the building with only three basic elements: a floor slab, columns and a roof plate" (Mies van der Rohe, 1943, p. 84).

Finally, from this viewpoint of the search for the essence of things, it is important to understand the notes that Mies wrote as a sort of script for the lectures he gave around 1950, documents that date moreover from the start of the design of Crown Hall (published in Neumeyer, 1991, pp. 325-328). About function, Mies again champions the need to re-establish the meaning and order of things, i.e., to ask oneself what they are and what they are for, so that they can occupy their rightful place based on their essence. Only thus can one create effective forms rather than forms full of effectiveness. Structure was now the only element able to withstand the renewal of architecture itself (Santatecla, 2005).

A brief review of this evolution shows that his writings during his teaching period in the US reveal the increasingly relevant and essential role of structure. But is the same evolution found in the curricula he created as head of the department of architecture and in the master's dissertation projects that he directed when head of the graduate program at IIT? Mies accepted the post of head of the department of architecture st AIT on condition he could restructure the curriculum included for the first time in the 1939 Academic Bulletin. The undergraduate curriculum was spread over four years, all based on a teaching method, which "interrelat[e] the different fields of instruction that the student is always conscious of, and is always working in the whole sphere of architecture in its fullest sense of designing a structure for a purpose, ordering it so that it attains significance as art, and working out the conception so that it may be realized in the executed building" (Bulletin of the AIT, 1939, p. 44).

Mies was also in charge of the graduate program that led to the degree of Master of Science in Architecture. In order to obtain this degree, it was necessary to take the Advanced Architecture courses, taught by Mies himself, and whose objectives were stated by him in 1939 in the new curriculum in the following order of importance: "(1) The structure as an architectural factor; its possibilities and limitations, (2) Space as an architectural problem, (3) Proportion as a means of architectural expression, (4) The expression value of materials. (5) Painting and sculpture in their relationship to architecture, and (6) The application of these principles by means of free creative work" (Bulletin of the AIT, 1939, p. 49).

Whereas the undergraduate curriculum did not place too much emphasis on structural contents, the graduate curriculum defines structure as the first shaping factor of architectural space. However, whereas the graduate program remained unchanged during Mies' 20-year tenure as director, the

ACE, 15 (4.5) CC BY-ND 3.0 ES | UPC Barcelona, España | Mies and his Teaching Venues. The Triumph of 15 Architecture over Function. DOI: http://dx.doi.org/10.5821/ace.15.45.9517 
undergraduate program did not. The first change was made in 1941, at which time a fifth optional course began to be offered, in which the student could choose to finish their studies in the specialty of Architectural or City Planning. The second change took place in 1949, the year in which the fouryear degree became a five-year degree: the first three years consisted of Fundamental Training and the last two, Architectural Principles: six principles that corresponded to the six objectives set out in 1939, i.e., those in the graduate courses of Advanced Architecture. Therefore, the importance of the structure that was implemented as a degree in 1949 is evident, acquiring an importance similar to that of the Master's degree since 1939: from now on structure was the first architectural factor to be taken into account in the teaching of architecture from the beginning of the learning process.

\section{4. "A School of Architecture": Chicago, 1956-59. Universal Space}

Having analysed the venues where Mies taught prior to Crown Hall and examined one of his essays about the key factors in his architectural concepts, the next step is to consider whether these precedents influenced the design of Crown Hall. This was one of his flagships, open-plan projects: firstly, because this place is unlike the usual typologies used for schools of architecture, art or design in that period, and secondly because Mies had never designed a building of this sort or an open-floor plan of that size before. "Despite this space being divided into two due to the location of the entrance and the layout of the unmovable components along its axis of symmetry, it was nonetheless a seamless space that constituted a large ideal space for teaching the different subjects in his curriculum" (Santatecla et al., 2010, p. 52) and "reflect an education system centred on the studio work" (Cohen, 2018, p. 118). The result was one of the most highly acclaimed places for teaching architecture and even today, more than seventy years later, it continues to fulfil this purpose. At crown Hall, architecture undoubtedly transcends function.

Crown Hall was the first and only school of architecture that Mies designed although he had considered this type of building during his time as a teacher and head of the IIT post-graduate programme. As mentioned above, unlike the Bauhaus, the new IIT school of architecture taught not only a bachelor's degree but also a graduate programme in architecture. The five-year curriculum culminated in the two-year master's degree when students had to write a master thesis project which put into practice the knowledge acquired in previous years. They situated each project in a specific context, defined the functional requirements of the chosen type of building, and developed a structural system that tallied with the scale and nature of the building (Chang \& Swenson, 1980). According to comments by students, "the architecture studio became a research laboratory for thinking about the problems he confronted in practice" (Harrington, 1986, p. 60). His architecture and classes had a common goal: to unearth the essence of architecture, be it in the classroom, in the studio or on site $^{6}$. Consequently, as in the case of the court houses at the Bauhaus, it is no coincidence that many of the projects by his IIT students involved the same type of constructions as his professional projects, as can be seen in Figure 3 showing details of the thesis projects housed in the Graham Resource Center and the IIT archives. For the purpose of the present article, it would, therefore, be useful to know which post-grad projects involved joint research by students and Mies about the creation of a new concept of space in which architecture could be taught and practiced.

As Figure 3 shows, only two of the theses by students of Mies' focus specifically on educational establishments: one written before Crown Hall was designed, and one afterwards. The first one was

\footnotetext{
6 "The constant search involved in his approach to architecture reflected that the classroom became a second intellectual laboratory to his office (...) A fluid relationship developed between his office and classroom, and problems crossed freely between the two realms of theory and practice. It was not unusual for a graduate thesis to develop alongside a current office project, and it was even more likely that a student project would address a program which had already been brought to resolution in the office, and possibly even built" (McAtee, 1996, p. 77).
} 
the master's degree thesis dated June 1941 by Charles Worley, tutored by Walter Peterhans and directed by Mies van der Rohe, entitled A School of Art and Architecture. Its Theory and Development (Worley, 1941). The other one was Architecture and Design Building by Frederick Peter Seidel, dated June 1953 and directed by Hilberseimer, with comments and advice from Mies van der Rohe (Seidel, 1953).

In brief, it may be said that Worley's project describes two basic criteria that a place where architecture is taught must comply with. He begins by stating the need for "a modern style of architecture (...) a building as an expression of a culture during a certain epoch” (Worley, 1941: 3), a principle inspired by Mies' oft-repeated words: architecture is always linked to a period and can only manifest itself through living tasks and the means of its time. The second criterion outlined by Worley is useful when compared with Mies' manifestos because it outlines the concepts of the fluid, open space that Mies himself created years later in the open plan of Crown Hall. As regards spatial considerations, Worley suggested that schools of architecture should aim to be open plan: "an attempt was made to find a solution with all the students working in a large hall, with only those functions which obviously require privacy separated from the work room" (Worley, 1941, p. 25). As regards constructive considerations, he said that "the constructive type is a steel frame. This construction makes it possible to erect a building with only two plastic elements, the roof plate (above the ground of columns) and the floor slab" (Worley, 1941, p. 25).

Figure 12. Comparative drawings of (left) floor plan and façade, Museum for a Small City, 1942, Mies van der Rohe, and (right) the School of Art and Architecture, Charles Worley, 1941

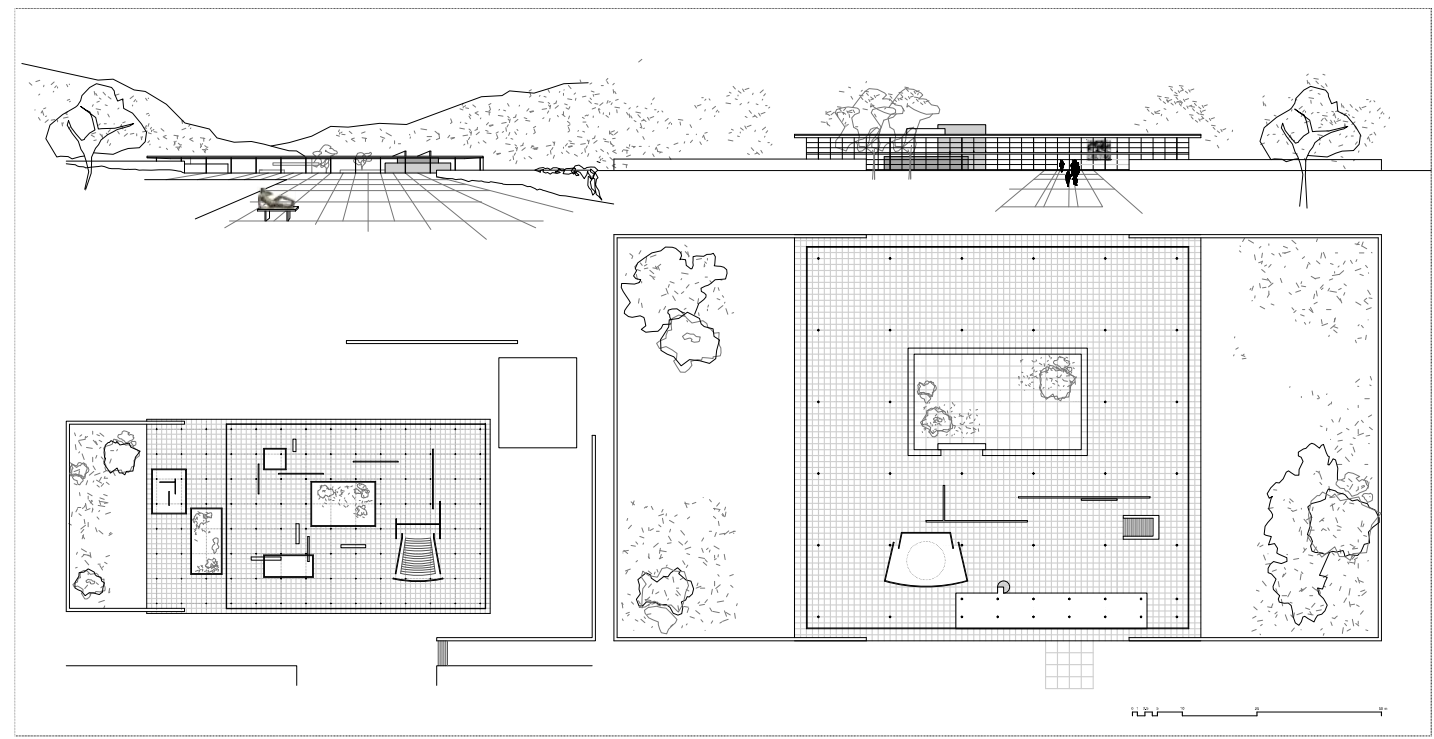

Source: Authors' drawing based on the archive research.

It is surprising that some of the concepts Worley wrote about in 1942 were mentioned by Mies a year later in his Museum for a Small City essay. Despite resolving certain functional issues, there are obvious similarities. They both begin by asking what a museum and a school should be and they both reach the same conclusion: an open-plan space enabling maximum flexibility based on a roof mounted on metal columns. In Worley's open-plan design, service and storage areas are relegated to the basement. As a result, the main floor is a large room remarkably like the one designed by Mies for the Museum for a Small City: an open-plan area compartmentalised by sliding walls and patios laid out along a precise, metal grid of equidistant cruciform columns with elaborate riveted unions. Likewise, the building in each project consists of just a few architectural elements, all of which are structural and made of metal: Worley mentions two plastic elements, i.e., the roof plate supported by columns and the floor slab whilst Mies describes the same concept for the museum in virtually 
the same words?. In addition, there are obvious spatial and structural similarities between Worley's drawings of the school of art and architecture and those in the Museum for a Small City project (see Figure 12).

The thesis written by F.P. Seidel twelve years later also emphasises that a school of architecture must "encourage communication among students and ... be flexible enough to permit different arrangements" (Seidel, 1953, p. 8). Once again, Seidel's project entails a two-storey building that is only flexible thanks to its open-plan, steel skeleton: a basement for more private functions and a ground floor for teaching areas. The latter is a large open space consisting of a grid of rolled-steel, Double-T columns visible on the inside but set around the perimeter as part of the outside wall. This square area measuring 216 feet along each side is divided into three parts. The middle section features a raised exhibition area whose structure is hidden. The resulting module, layout of the north and south entrances, the mezzanine and the interaction between the brick plinth, glass panels and the structure are very reminiscent of the project for the new school of architecture that Mies was working on at that time (see Figure 13).

Figure 13. Comparative drawings of (left) floor plan and south and west façades, Architecture and Design Building, 1953, Frederick P. Seidel, and (right) initial proposals for Crown Hall, Mies van der Rohe, 1953

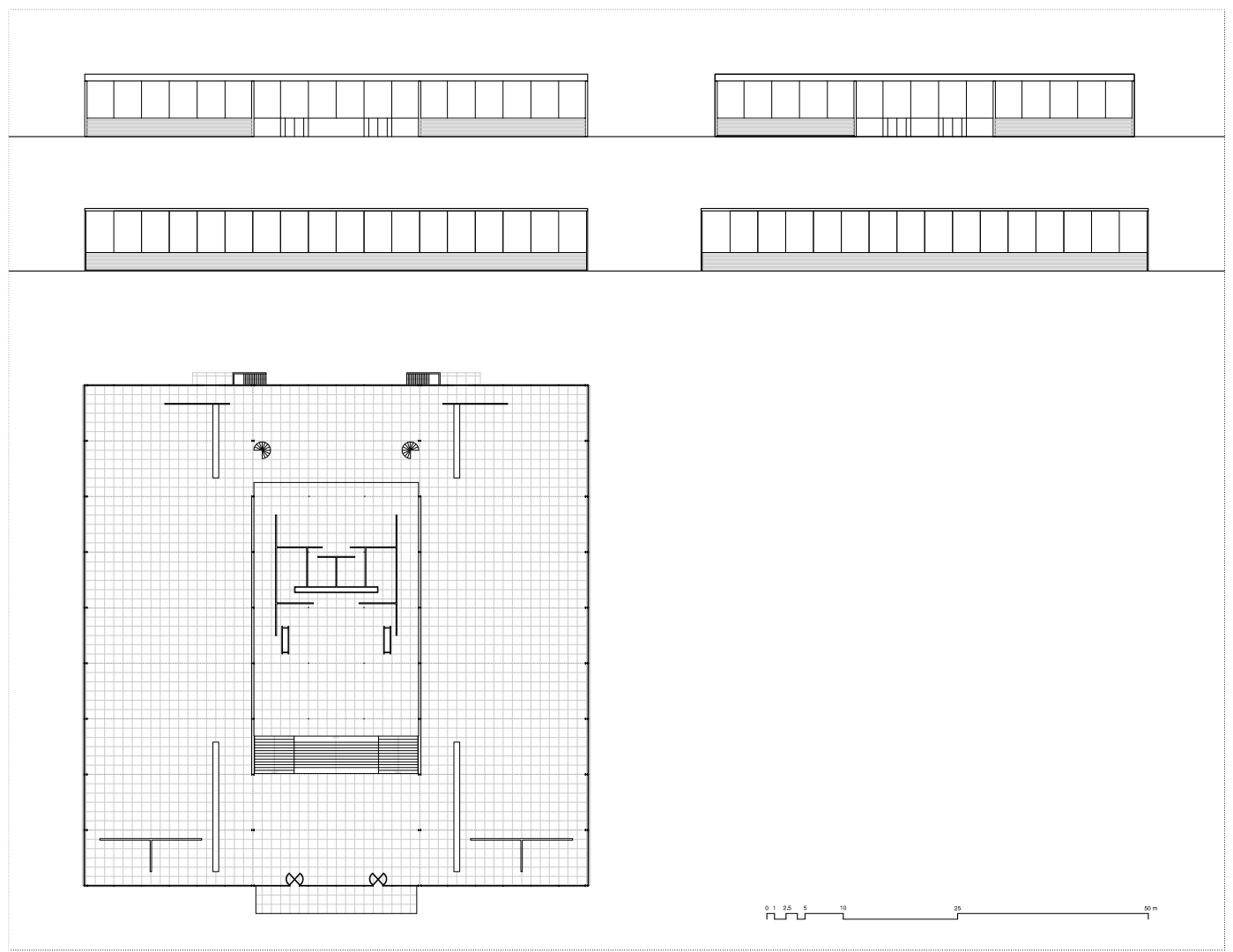

Source: Authors' drawing based on the archive research.

After the above analysis, it may be said that although the Crown Hall project began in 1950, the search for the most suitable space for teaching architecture had been an issue in Mies' critical thinking for

\footnotetext{
${ }^{7}$ According to research by Cammie McAtee, the Museum for a Small City also stemmed from the master's degree thesis by the IIT student George Edson Danforth. (McAtee, 2000, pp. 219-247).
} 


\section{ACE Architecture, City and Environment}

E-ISSN 1886-4805

some time and in his theoretical and practical research during his years as a professor and architect. It became so patently obvious to Mies that he had to build a universal space with huge one-way spans that he ignored the rules that he had drawn up personally ten years earlier whilst working on the IIT campus project. For Crown Hall, Mies cast aside the humble language of factory brick in favour of a sophisticated steel-and-glass building and a 24-foot module (Lambert, 2001. P. 448).

Whereas the earlier buildings revealed Mies' fondness for larger spaces as teaching areas, in the openplan Crown Hall he had no other option. He did not have to choose the best-lit area either because the entire building was well illuminated. Nor did he have to worry about the intermediary structure because there was none: the entire structure was shifted outwards, leaving an entirely open-plan interior 120 feet wide by 220 feet long and 18 feet high. From the outside, the school's structure seems to defy the laws of gravity: the portal frames of the school, which is built 6 feet above the ground, seem to disregard the logical transmission of loads; the welded plate girders are not located underneath the roof-slab, they stand out and acquire a character of their own by being positioned above the roof-slab. The connections between the columns and the roof-slab barely exist they are impeccably welded and virtually invisible. The structure seems weightless, the roof-slab is not heavy and hangs from the lower edge of the girder as if it might fly away at any moment were it not for the gentle grasp of the girders that stop it from being blown into the sky (see Figures 14 \& 15).

In other words, Mies designed an imaginary, enlargeable space suitable for an architecture without a function: "his first large-scale, clear-span, universal-space building (...) a place where all teachers and all students, regardless of their levels of experience, could come together and work, literally within sight and reach of each other" (Drexler \& Schulze, 1985, p. 206). A universal space regarded as "the curriculum raised to three dimensions" (Harrington, 1986, p. 64). A cultured, unitary and technological architecture in which what matters is not the functional program but the concept, in which architecture transcends function. A search for not only a universal space but universal validity (Boyken, 1990, p. 133), the constantly pared down architecture based on an idea that can be repeated, be anonymous, and be increasingly abstract and essential.

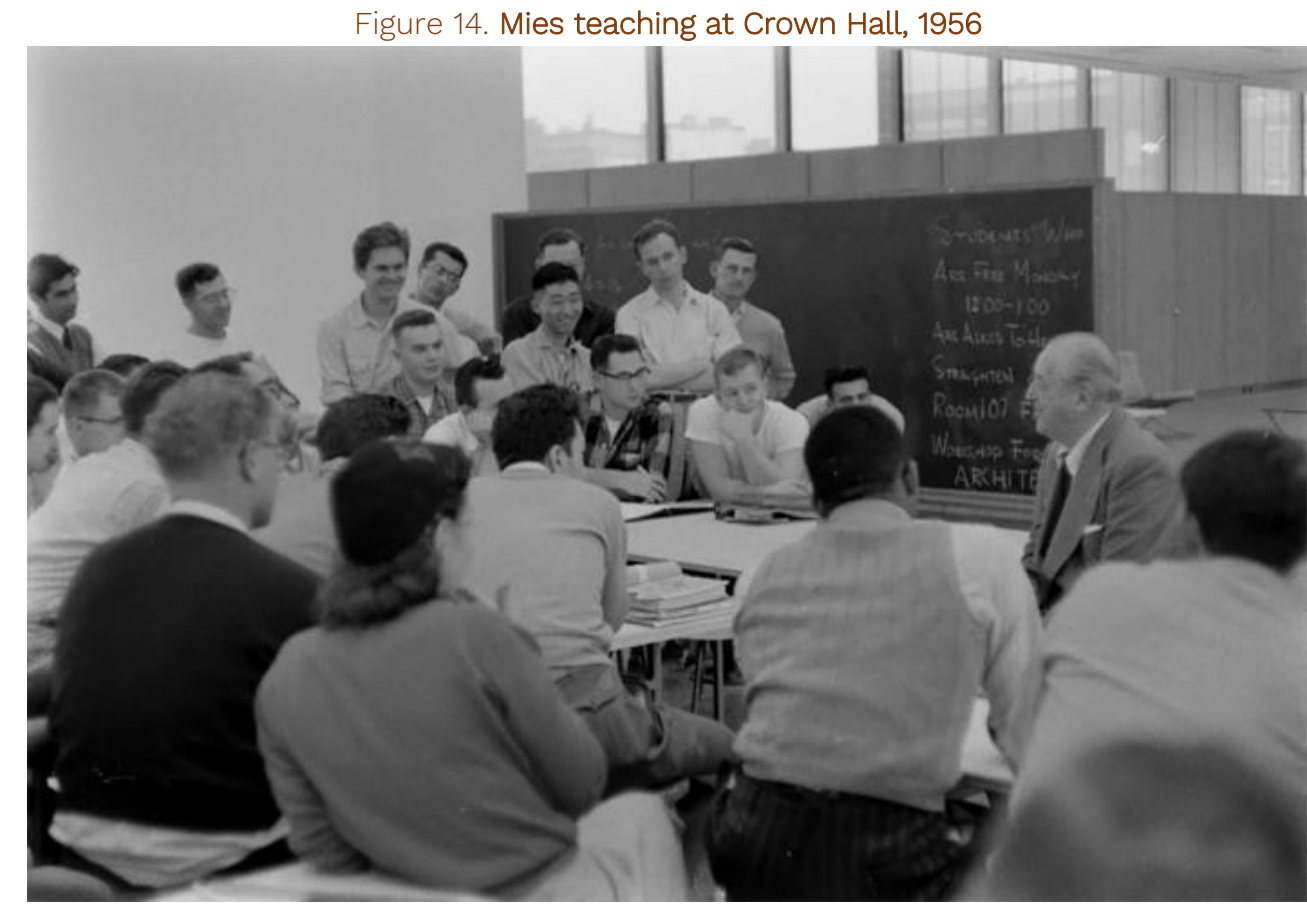

Source: LIFE (CTime Inc.

ACE, 15 (4.5) CC BY-ND 3.0 ES | UPC Barcelona, España | Mies and his Teaching Venues. The Triumph of

Architecture over Function. DOI: http://dx.doi.org/10.5821/ace.15.45.9517 
Figure 15. Upper level, S. R. Crown Hall, IIT Chicago, Mies van der Rohe, 1956. In grey: School of Architecture = Lecture room with furniture (Mies' class)

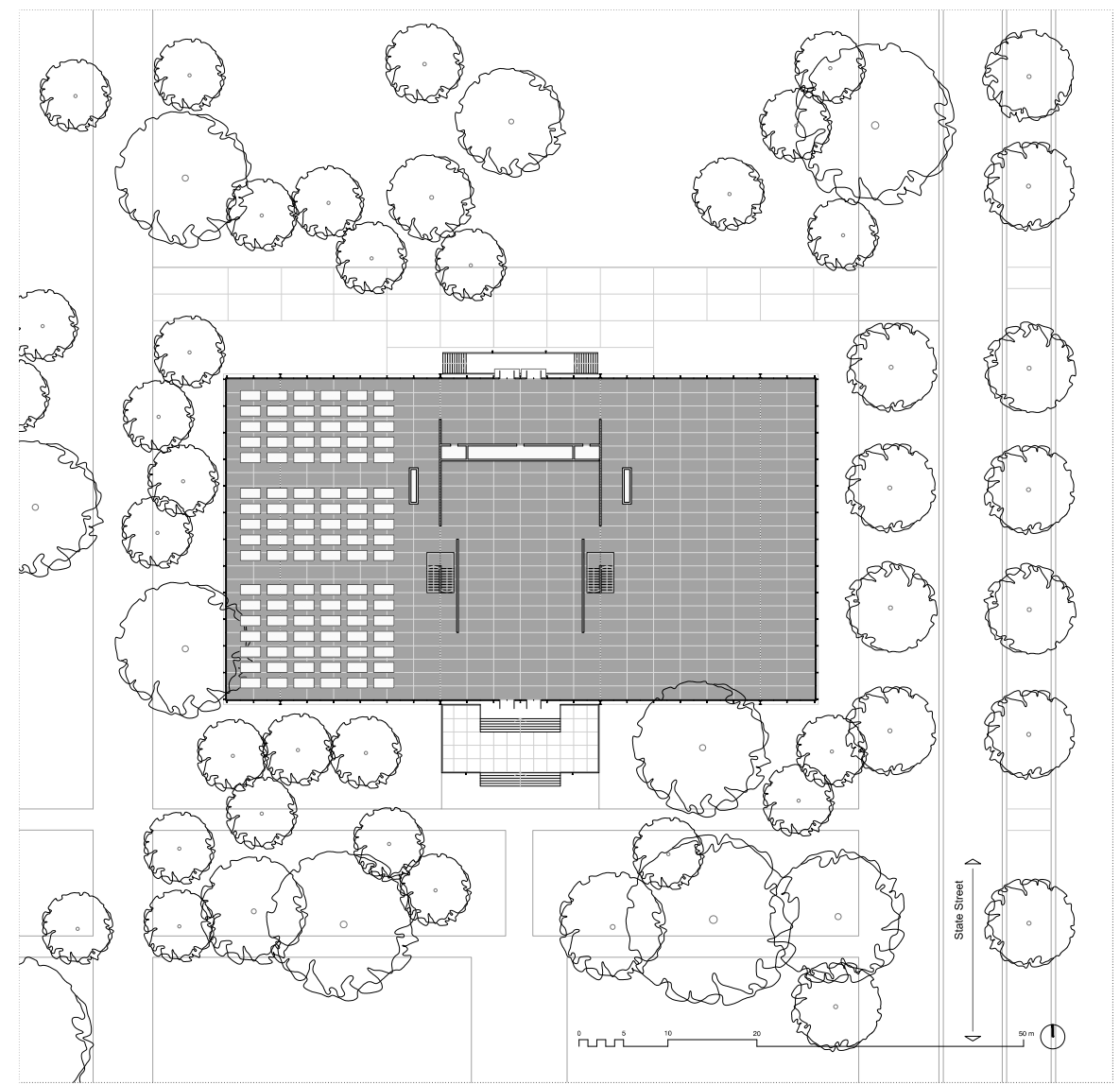

Source: Authors' drawing

\section{Conclusion}

This paper has examined the connection between Mies van de Rohe, as a teacher and professional architect, and schools of architecture as a typology, to answer the following question: To what extent did Mies' teaching experience and the homologous projects he was professionally and academically involved in play a decisive role in the design of Crown Hall?

By examining the different venues in which Mies taught architecture and comparing them with his writings, work and activities as a professor of architecture, the present article reveals how the architectural thinking of Mies evolved from the compartmentalised distribution of the Berlin Bauhaus, whose meticulous functional program provided specific spaces that could only be used for the purpose for which they were designed, to the enormous open space of Crown Hall that could be used for virtually any purpose.

Indeed, Mies highlights his approach to function in his immediate response to the urgent need to reopen the Bauhaus in Berlin. The main purpose of the project was to satisfy not just existing basic needs but also the spiritual needs of a certain group in society with avant-garde cultural interests, i.e., future architects. However, Crown Hall consists essentially of an open-plan space between two floors. The concept of function spreads into the sphere of meanings and pure art, in short, into the 
realm of essentials. In that phase, it was not merely a matter of organising a complex functional program but, as Mies himself said, one should ask oneself "Where do we go from here? We are not at the end but at the beginning of a new epoch..." (Mies, 1960, p. 391). In other words, the following questions must be answered: What is a school of architecture? What sort of space is best for teaching architecture? What aspects are important? Which can remain the same? For, as Mies also said, "it is of course not necessary or possible to invent a new architecture each Monday morning” (Mies, 1960, p. 391).

The gradual side-lining of function in Mies' projects is inversely proportional to the increasing importance of structure in his architecture. Prior to the Museum for a Small City project, the fabric of beams and columns in the steel structure constituted an independent whole that was inserted into the architecture and imposed its own order by means of the columns visible inside the most characteristic areas. Mies interacted not only with structure as part of the interior of the spaces in which he taught, but also in the buildings he erected and the student projects he supervised. The Museum for a Small City project marked the start of Mies' path towards architectural liberation. He began to rid his architecture of all non-essentials, placing increasing emphasis on structure. His search for the essence of architecture reached the structure. Beams and columns gradually moved outwards in an obvious declaration of the essence of their materials and manufacturing processes. Each structural component, without losing its own identity, occupies the rightful place determined by its essence (see Figure 16).

Figure 16. Evolution of Mies' approach to function and structure

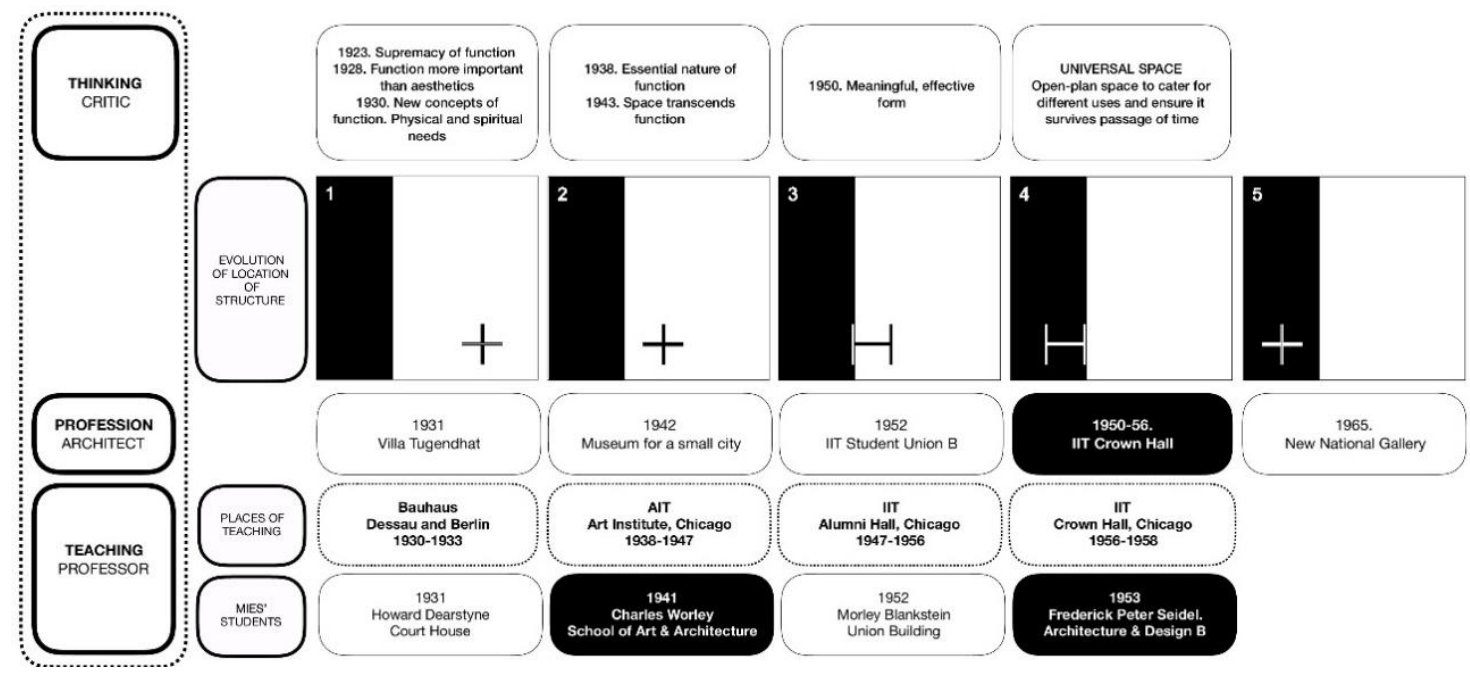

Source: Own elaboration based on the research.

In order to demonstrate these academic arguments, the only two post-graduate dissertations about the school of architecture typology which were directed by Mies were studied by the authors and then compared with his writings and architecture. Said comparison reveals that structure evolved in a similar manner. Both Worley's dissertation and the Museum for a Small City proposal begin by questioning what the project should be, and both conclude that it should be a unitary space enabling maximum flexibility and configured by three basic elements, all structural. A few years later, in keeping with his writings, Seidel's project shows a path towards structural synthesis, and proposes a space that remains unitary but is continuous and without courtyards, a space seeking to detach itself from the structure and which therefore simplifies the columns and moves them outwards. The close links between Worley's dissertation and the Museum for a Small City, and Seidel's dissertation and the recently built Minerals and Metals Building at the IIT and the proposal for Crown Hall, confirm that teaching and architecture are inseparable for Mies van der Rohe. What is more, the authors' analysis 
of these factors has led to important findings including the fact that some of his students' projects, like conceptual laboratories, anticipated his thoughts. Thus, in the words of his students, "the constant search involved in his approach to architecture reflect that the classroom became a second intellectual laboratory to his office (...) A fluid relationship developed between his office and classroom, and problems crossed freely between the two realms of theory and practice" (McAtee, 1996, p. 77).

In short, the answer to the question underpinning this paper is clearly affirmative. The architecture of Mies van der Rohe is the convergence of his three fields of work (Mies the critic, Mies the architect and Mies the professor) and in all three, structure gradually assumes the central role of his discourse. Thus, the space intended to be universal, fluid and long-lasting is designed based on its structure because it "expresses the meaning, expresses it down to the last remnant of spiritual value" (lecture published in Neumeyer, 1991, p. 325). In other words, structure not only determines form but is form itself.

\section{Authorship}

The first author has been in charge of structuring and carrying out the overall preparation of the manuscript, based on joint research written together with the other authors. She has also redrawn the plans from the archive documents. The second author has contributed to the interpretation of German texts and the writing of the article, making key contributions to all aspects of Mies van der Rohe's thinking, the topic he investigated in his doctoral thesis. The third author visited the IIT archives and made an inventory of the unpublished material used in the article. She has contributed to the redrawing of plans in relation to the theses of IIT students, the subject of her doctoral thesis.

Competing Interests: The authors have no competing interests to declare.

\section{Bibliography}

Añón Abajas, R.M. (2010). The Bauhaus, from Dessau to Ulm: essays on this high yield educational space. Proyecto, Progreso, Arquitectura, 1(1), 26-45. DOI: https://doi.org/10.12795/ppa.2010.i1.02

Banham, R. (1986). The master of humane Architecture. In: Achilles, R., \& K. Harrington (Eds.), Mies van der Rohe: Architect as Educator 1938-1978 (pp. 13-16). Chicago: Illinois Institute of Technology.

Boyken, I. (1990). Ludwig Mies van de Rohe and Egon Eiermann: The Dictate of Order. Journal of the Society of Architectural Historians, 49(2), 133-153. DOI: https://doi.org/10.2307/990473

Bulletins of the Armour Institute of Technology. (1939, May). Armour Institute of Technology. [UASC, Galvin Library, IIT, Chicago, United States].

Burleigh, T. (1998, September 18). The Art Institute. IIT's downtown Campus [Rough draft. The Art Institute of Chicago, Ryerson \& Burnham Archives, Thomas R. Burleigh Collection 1940-2000, Box. FF.2.3].

Chang, P.C., \& Swenson, A. (1980). Architectural Education at IIT. Chicago: Illinois Institute of Technology.

Cohen, J-L (2018). Ludwig Mies van der Rohe. Basel: Birkhäuser. 
Dearstyne, H. (1944). Basic Teaching of Architecture. Liturgical Arts, 12(May), 1-10.

Dearstyne, H. (1962). The Bauhaus Revisited. Journal of Architectural Education, 17(October), 13-16. Published online: 25 November 2015. DOI: https://doi.org/10.1080/00472239.1962.11102164

Dearstyne, H. (1986). Inside the Bauhaus. London / New York: Architectural Press / Rizzoli International Publications.

Drexler, A and Schulze, F. (Eds.). (1985). Mies van der Rohe Archive 1910-1937. New York: MoMA.

Fornari Colombo, L. (2015). The Miesian courtyard house. Architectural Research Quarterly, 19(2), 123132. DOI: https://doi.org/10.1017/\$1359135515000378

Giedion S. (1954). Walter Gropius. Mensch und Werk. Stuttgart: Verlag Gerd Hatje.

Hahn, P. (1985) Bauhaus Berlin. Auflösung Dessau 1932, Schließung Berlin 1933. Bauhäußler und Drittes Reich. Weingarten: Kunstverlag Weingarten.

Harrington, K. (1986). Order, Space, Proportion - Mies curriculum at IIT. In: Achilles, R., \& K. Harrington (Eds.), Mies van der Rohe: Architect as Educator 1938-1978 (pp. 49-68). Chicago: Illinois Institute of Technology.

Hochman, E. (1989). Architects of Fortune: Mies van der Rohe and the Third Reich. New York: Weidenfeld \& Nicolson.

Honey, S. (1978). Mies at the Bauhaus. Architectural Association Quarterly 10(1), 52-59.

Honey, S. (1986). Mies van der Rohe: Architect and teacher in Germany. In: Achilles, R., \& K. Harrington (Eds.), Mies van der Rohe: Architect as Educator 1938-1978 (pp. 37-48). Chicago: Illinois Institute of Technology.

Lambert, P. (2001). Mies in America. New York: Harry N. Abrams: Whitney Museum of American Art. Hatje Cantz: Canadian Centre Architecture.

Lizondo Sevilla, L., Santatecla Fayos, J., Martínez García, S. \& Bosch Reig, I. (2014) La influencia de la arquitectura efímera en la arquitectura construida. El caso de Mies van der Rohe. ACE: Architecture, City and Environment, 8 (24), 73-94. DOI: https://doi.org/10.5821/ace.8.24.2717

Malcolmson, R.F. (1959). A Curriculum of Ideas. Journal of Architectural Education, 14 (2), 41-43. Published online: 22 May 2015. DOI: https://doi.org/10.1080/10464883.1959.11102417

Malcolmson, R.F. (1986). The school of Mies van der Rohe: A Philosophy of Architectural Education [Manuscript. The Art Institute of Chicago, Ryerson \& Burnham Archives, George Danforth Collection 1921-2007, Box 1.11].

McAtee, C.D. (1996). Mies van der Rohe and Architectural Education. The Curriculum at the Illinois Institute of Technology. Students' Projects and Built Work (M.A.Diss.). Queen's University Kingston, United States.

McAtee, CD. (2000). Le musée pour une petite ville. Genesis, 14, 219-247. 
Mies van der Rohe. (1923). Gelöste Aufgaben. Eine Forderung an unserem Bauwesen [Lecture]. Published in: Die Bauwelt, 14(52), 719.

Mies van der Rohe. (1930). Schön und praktisch bauen! Schluß mit der kalten Zweckmässigkeit. Duisburger General Anzeiger, 26 January, 2.

Mies van der Rohe. (1938). Inaugural Address as Director of Architecture at Armour Institute of Technology [Speech]. Published in: Johnson, P. (1947). Mies van der Rohe. New York: Museum of Modern Art.

Mies van der Rohe. (1943). New Buildings for 194X. Architectural Forum, 78(May), 69-85.

Mies van der Rohe. (1951). Proceedings of the 37th Annual Convention. Journal of Architectural Education, 7(1), 13-16. Published online: 22 May 2015. DOI: https://doi.org/10.1080/10464883.1951.11102328

Mies van der Rohe. (1960). Wohin gehen wir nun? Bauen und Wohnen, 15(11), 391.

Neumeyer, F. (1986). Mies as self-Educator. In: Achilles, R., \& K. Harrington (Eds.), Mies van der Rohe: Architect as Educator 1938-1978 (pp. 27-36). Chicago: Illinois Institute of Technology.

Neumeyer, F. (1991). The Artless Word: Mies van der Rohe on the Building Art. London/Cambridge: The MIT Press.

Neumeyer, F. (2019, October) Lliçó inaugural 2019-20. Mies van der Rohe-Outside the Bauhaus. [Lecture]. Retrieved from https://etsab.upc.edu/ca/futurs-estudiants/que-fem/qf-llicons

Riley, T. (2001). From Bauhaus to Court-house. In: Riley, T., \& B. Bergdoll (Eds.), Mies in Berlin (pp. 330337). New York: The Museum of Modern Art.

Santatecla Fayos, J, Mas Llorens, V., \& Lizondo Sevilla, L. (2010). The Crown Hall. Context and Project. Proyecto, Progreso, Arquitectura, 1(May), 46-59. DOI: http://dx.doi.org/10.12795/ppa.2010.11.03

Santatecla Fayos, J. (2005). De la esencia de la arquitectura a lo esencial del espacio. Forma y concepto en la arquitectura de Mies van de Rohe (Tesis doctoral) Universitat Politècnica de València, España. Retrieved from https://riunet.upv.es/handle/10251/2628

Schulze, F., \& Windhorst, E. (2012). Ludwig Mies van der Rohe. A critical biography, new and revised edition. Chicago and London: The University of Chicago Press.

Seidel, F.P. (1953). Architecture and Design Building (Degree of Master of Science in Architecture) Graduate School of Illinois Institute of Technology, United States.

Worley, C.S. (1941). A School of Art and Architecture - Its Theory and development (Degree of Master of Science in Architecture) Graduate School of Illinois Institute of Technology, United States. 